\title{
Single-Dose Gamma-Irradiation Induces Up-Regulation of Chemokine Gene Expression and Recruitment of Granulocytes into the Portal Area but Not into Other Regions of Rat Hepatic Tissue
}

\author{
Ihtzaz Ahmed Malik, ${ }^{*}$ Federico Moriconi, ${ }^{*}$ \\ Nadeem Sheikh, ${ }^{*}$ Naila Naz, ${ }^{*}$ Sajjad Khan, ${ }^{*}$ \\ Jozsef Dudas, ${ }^{*}$ Tümen Mansuroglu, ${ }^{*}$ \\ Clemens Friedrich Hess, ${ }^{\dagger}$ Margret Rave-Fränk, ${ }^{\dagger}$ \\ Hans Christiansen, ${ }^{\dagger}$ and Giuliano Ramadori ${ }^{\star}$ \\ From the Division of Gastroenterology and Endocrinology, \\ Department of Internal Medicine, * and Department of Radiation \\ Oncology, ${ }^{\dagger}$ University Hospital, Georg-August-University, \\ Göttingen, Germany
}

Liver damage is a serious clinical complication of $\gamma$-irradiation. We therefore exposed rats to singledose $\gamma$-irradiation (25 Gy) that was focused on the liver. Three to six hours after irradiation, an increased number of neutrophils (but not mononuclear phagocytes) was observed by immunohistochemistry to be attached to portal vessels between and around the portal (myo)fibroblasts (smooth muscle actin and Thy-1 ${ }^{+}$cells). MCP-1/CCL2 staining was also detected in the portal vessel walls, including some cells of the portal area. CC-chemokine (MCP-1/CCL2 and MCP-3/CCL7) and CXC-chemokine (KC/CXCL1, MIP2/CXCL2, and LIX/CXCL5) gene expression was significantly induced in total RNA from irradiated livers. In laser capture microdissected samples, an early (1 to 3 hours) up-regulation of CCL2, CXCL1, CXCL8, and CXCR2 gene expression was detected in the portal area but not in the parenchyma; with the exception of CXCL1 gene expression. In addition, treatment with an antibody against MCP-1/CCL2 before irradiation led to an increase in gene expression of interferon- $\gamma$ and IP-10/CXCL10 in liver tissue without influencing the recruitment of granulocytes. Indeed, the CCL2, CXCL1, CXCL2, and CXCL5 genes were strongly expressed and further up-regulated in liver (myo)fibroblasts after irradiation (8 Gy). Taken together, these results suggest that $\gamma$-irradiation of the liver induces a transient accumulation of granulocytes within the portal area and that (myo)fibroblasts of the portal vessels may be one of the major sources of the chemokines involved in neutrophil recruitment. Moreover, inhibition of more than one chemokine (eg, CXCL1 and CXCL8) may be necessary to reduce leukocytes recruitment. (Am J Pathol 2010, 176:1801-1815; DOI: 10.2353/ajpath.2010.090505)

Radiation therapy has played a minor role in the treatment of patients with liver cancer or liver metastases because the liver has been considered sensitive to radiation. Indeed, radiation-induced liver disease is a serious clinical complication, ${ }^{1}$ due chiefly to radiation-induced inflammation. Radiation-induced liver damage seems to be worse if the diseased liver is irradiated. ${ }^{2}$

Chemokines are thought to be responsible for recruiting inflammatory cells. They are actively involved in inflammation, tissue repair, and development of fibrosis. ${ }^{3}$ The chemokine family is divided into four main groups based on their structure and chemotactic activity for specific leukocyte populations: $\mathrm{C}, \mathrm{CC}, \mathrm{CXC}$, and $\mathrm{CX}_{3} \mathrm{C}$. The subset of CXC chemokines containing a glycine-leucinearginine (ELR) motif, which immediately precedes the CXC residues, selectively targets neutrophils. Although there are seven ELR ${ }^{+} \mathrm{CXC}$ chemokines in the human genome, only four have been identified in the murine genome: keratinocyte-derived chemokine (KC)/CXCL1, macrophage-inflammatory protein-2 (MIP-2)/CXCL2, lipopolysaccharide-induced chemokine (LIX)/CXCL5, and CXCL15/lungkine. ${ }^{4-6}$

The CXC (or $\alpha$ ) chemokines, such as interleukin-8 (IL-8)/CXCL8, CXCL9/MIG, CXCL10/IP-10, CXCL11/ITAC,

Supported by grants from the Deutsche Krebshilfe (Project 108774) and Bundesamt für Strahlenschutz (StSch4546)

Accepted for publication December 15, 2009.

Supplemental material for this article can be found on http://ajp. amjpathol.org

Address reprint requests to Giuliano Ramadori, M.D., Department of Internal Medicine, University Hospital Göttingen, Robert-Koch-Str. 40, 37075 Göttingen, Germany. E-mail: gramado@med.uni-goettingen.de. 
and CXCL12/SDF1, have the potential to activate and attract neutrophils and T Iymphocytes, ${ }^{7}$ whereas the CC (or $\beta$ ) chemokines, such as monocyte chemoattractant protein-1 (MCP-1)/CCL2, MIP-1 $\alpha / C C L 3$, MIP-1 $\beta / C C L 4$, MIP-3 $\alpha / C C L 20$, and MIP-3 $\beta / C C L 19$, are predominantly chemoattractants for multiple leukocyte subtypes, including monocytes, eosinophils, basophils, T lymphocytes, dendritic cells, natural killer cells, and, to a lesser extent, neutrophils. ${ }^{8}$ Neutrophil recruitment is regulated by a complex array of signals, ${ }^{9}$ including activated complement and the CXC family chemokines IL-8/CXCL8 or CINC-1, MIP-2/CXCL2, cytokine-induced neutrophil chemoattractant (KC/CXCL1/Gro- $\alpha$ ), and LIX/CXCL5. ${ }^{10,11}$ This process is regulated at multiple levels, but it may also depend in part on the local production of chemoattractant cytokines (interferon- $\gamma[\mathrm{IFN}-\gamma]$, tumor necrosis factor- $\alpha$, etc) or chemokines that function to modulate the activity of cell-surface adhesion receptors as well as to direct migration of targeted cells into the tissue site. ${ }^{10,12}$

Among the most thoroughly characterized chemokines are the MCPs. MCPs attract cells through activation of their cognate receptor, CC-chemokine receptor 2 (CCR2). MCP-1/CCL2 is expressed in the monocytes, neutrophils, endothelial cells, epithelial cells, fibroblasts, and hepatocytes. ${ }^{13,14}$ Mice that are genetically deficient in CCR2 (CCR2 $^{-1-}$ mice) exhibit markedly reduced tissue recruitment of monocytes in autoimmune encephalitis, ${ }^{15}$ tuberculosis, ${ }^{16}$ and atherosclerosis. ${ }^{17}$ Previous reports showed more liver injury in mice that lack CCR2, the receptor for CCL2, compared with wild-type mice, and this susceptibility was related to an increase in levels of IFN- $\gamma$ and tumor necrosis factor- $\alpha .{ }^{18}$ MCP-1/CCL2 and MCP-3/CCL7 are the CCR2 agonists and have a well-established role in recruiting monocytes to sites of inflammation. Furthermore, reduced mobilization of monocytes from the bone marrow to the peripheral circulation in CCR2-deficient mice during peritonitis has been reported. ${ }^{19}$

CXCL1, CXCL2, and CXCL5 (their receptor is CXCR2) are CXC chemokines that promote chemotaxis of inflammatory cells to sites of inflammation. Induction of CXCL2 and CXCL5 was observed in myocardial cells in an ischemia-reperfusion rat model and also after lipopolysaccharide treatment. ${ }^{11}$ CXCL2 has been shown able to attract neutrophils to the site of inflammation..$^{20}$ Local expression of CXCL1 and of CXCL2 is important for neutrophil-dependent hepatic injury induced by ischemia and reperfusion in mice. ${ }^{21}$

In previous work, we have shown that single-dose $\gamma$-irradiation of rat liver changes the gene expression of several proteins including those of iron metabolism. ${ }^{22,23}$ Additionally, up-regulation of the genes of some proinflammatory chemokines (CINC-1/CXCL8, IP-10/CXCL10, ITAC/CXCL11, MCP-1/CCL2, MIG/CXCL9, MIP-1 $\alpha / C C L 3$, MIP-1 $\beta / C C L 4$, MIP-3 $\alpha / C C L 20$, MIP-3 $\beta / C C L 19$, and SDF1/ CXCL12) in $\gamma$-irradiated rat liver were observed, but gross histology did not show significant disturbance of the liver architecture by massive infiltration of inflammatory cells. ${ }^{24}$ Our aim for this work was to study the recruitment of inflammatory cells in different regions of rat liver tissue by means of immunohistology and to extend the analysis on additional chemokines known to be involved in recruitment of inflammatory cells. By means of immunohistology, we now show that irradiation induces a mild transient recruitment of granulocytes into the portal vessels but not into the sinusoids of the liver parenchyma. At the same time, a strong induction mainly of MCP-1/CCL2 and MCP-3/CCL7 was observed but also accompanied by an increase of CXCL2, CXCL5, and CXCL8 gene expression in the portal area. Recruitment of granulocytes into the portal field was also accompanied by upregulation of CXCR2 gene expression in this region. However, no increase of mononuclear phagocytes was observed at any time point after rat liver irradiation. Normal liver seems to be quite resistant to high single-dose $\gamma$-irradiation.

\section{Materials and Methods}

\section{Animals}

Male Wistar rats of about 170 to $200 \mathrm{~g}$ body weight were purchased from Harlan-Winkelmann (Brochen, Germany). The rats were kept under standard conditions with 12-hour light and dark cycles and ad libitum access to fresh water and food pellets. We adhered to the university's policies and relevant guidelines for care and use of laboratory animals. The treatment of the rats was reviewed, approved, and overseen by the local ethics committee of the University of Göttingen and the public authority on animal welfare.

\section{Antibodies}

A rabbit polyclonal antibody directed against rat neutrophil elastase (NE) was purchased from Calbiochem (Merck, Germany), and a mouse monoclonal antibody directed against rat $C D 11 \mathrm{~b} / \mathrm{c}$ came from BD Pharmingen (San Diego, CA). A mouse anti-rat ED1 monoclonal antibody (Serotec, Duesseldorf, Germany), a rabbit monoclonal anti-smooth muscle actin (SMA; Epitomics, Burlingame, $C A$ ), an anti-rat Thy-1 (BD Pharmingen), a goat polyclonal antiserum directed against MCP-1/CCL2 ( $R$ and D Systems, Wiesbaden, Germany), and an Armenian hamster monoclonal antibody directed against MCP-1 (Biolegend, München, Germany) were purchased. Antirat ED1, NE, and MCP-1/CCL2 were stained by using the peroxidase method as previously described. ${ }^{25} \mathrm{An}-$ ti-CD11b/c, anti-ED1, anti-SMA, and anti-Thy-1 antibodies were used for double immunofluorescence staining as described before. ${ }^{26}$

\section{Whole Liver Irradiation In Vivo}

The in vivo experiments were performed as described previously22: planning computed tomography was performed with a scanner (Somatom Balance; Siemens Medical Solutions, Erlangen, Germany) in each rat to delineate the livers of the animals. The rats were anesthetized intraperitoneally with $90 \mathrm{mg}$ ketamine per kilogram of body weight (Intervet, Unterschleissheim, Germany) and $7.5 \mathrm{mg} / \mathrm{kg}$ of $2 \%$ xylazine (Serumwerk Bernburg, Bern- 
burg/Saale, Germany). The margins of the liver were marked on the skin of the animals, and a dose distribution was calculated. The livers were irradiated selectively with $6 \mathrm{mV}$ photons (dose rate of $2.4 \mathrm{~Gy} / \mathrm{min}$ ) by using a Varian Clinac $600 \mathrm{C}$ accelerator (Varian, Palo Alto, CA); 25 Gy was delivered by using an anterior-posterior/posterioranterior (ap/pa) treatment technique. Treated animals (three for each time point) and sham-irradiated controls (three for each time point) were sacrificed humanely 1,3 , $6,12,24$, and 48 hours after irradiation.

In a separate experiment, a single dose of $250 \mu \mathrm{g} / \mathrm{kg}$ monoclonal anti-rat MCP-1/CCL2 antibody suspended in $0.5 \mathrm{ml}$ sterile sodium chloride $(0.9 \%)$ was injected intraperitoneally into the rat 30 minutes before irradiation. Animals were divided into four groups. Group 1 received only irradiation (25 Gy); group 2 received only MCP-1/ CCL2 antibody; group 3 received irradiation (25 Gy) and MCP-1/CCL2 antibody; and group 4 comprised salineinjected and sham-irradiated animals that served as controls. Treated animals (two for each time point) and shamirradiated controls (two for each time point) were sacrificed humanely 3 and 6 hours after irradiation. All groups were anesthetized and irradiated as described above.

\section{Measurement of MIP-2/CXCL2 and Liver Enzyme at Serum Level}

At time points ranging from 1 to 48 hours after irradiation of the rat livers, blood samples from the inferior vena cava were collected from control and irradiated rats and used for detection of CXCL2 in the serum of rats by using MIP-2/CXCL2 enzyme-linked immunosorbent assay kits from Biosource (Karlsruhe, Germany). The samples contained serum removed 1, 3, 6, 12, 24, and 48 hours after irradiation and were processed according to the suppliers' instructions. Furthermore, alkaline phosphatase was detected by using a standard $\mathrm{p}$-nitrophenolphosphate photometric assay (Roche, Mannheim, Germany). Aspartate aminotransferase (AST) and alanine aminotransferase (ALT) activities were measured by using analysis kits (DiaSys, Karben, Germany) as instructed.

\section{Liver Immunohistology and Cell Counting}

Five-micrometer cryostat sections were performed, airdried, fixed with acetone $\left(-20^{\circ} \mathrm{C}, 10\right.$ minutes $)$, and stored at $-20^{\circ} \mathrm{C}$. After inhibition of endogenous peroxidase by incubating the slides with PBS containing glucose/glucose oxidase/sodium azide, they were treated with fetal calf serum (FCS) for 30 minutes to minimize nonspecific staining. The sections were incubated in a humidified chamber with the first antibody directed against NE, ED1, ED2, CD11b/c, and CCL2 diluted in PBS at 1:100 for 1 hour at room temperature. Negative controls were obtained by incubating with isotype-specific mouse/rabbit/goat IgGs instead of the specific primary antibody. After washing, the slides were covered with peroxidase-conjugated anti-rabbit/anti-mouse/antigoat immunoglobulins preabsorbed with normal rat se- rum to avoid cross-reactivity. Slides were washed and incubated with PBS containing 3,3'-diaminobenzidine $(0.5 \mathrm{mg} / \mathrm{ml})$ and $\mathrm{H}_{2} \mathrm{O}_{2}(0.01 \%)$ for 10 minutes to visualize immune complexes. Nuclei were counterstained with Meyer's hemalum solution before slides were mounted with coverslips. The number of positive cells (NE, ED1, ED2, CD11b/c, and CCL2) was counted at each time point in the portal areas from 10 different portal vessels in the liver.

\section{RNA Isolation, Quantitative Real-Time RT-PCR, and Northern Blot Analysis}

Total RNA from the rat livers was isolated after homogenisation in guanidinium isothiocyanate (Sigma, Deisenhofen, Germany) by using the $\mathrm{CsCl}$ ultracentrifugation method as previously described. ${ }^{27}$ For real-time PCR, reverse transcription of RNA samples was performed by using the Superscript kit from Invitrogen (Groningen, Netherlands) and following the manufacturer's instructions. Real-time PCR analysis of cDNA was performed at $60^{\circ} \mathrm{C}$ to $95^{\circ} \mathrm{C}$ for 45 cycles in the Sequence Detection System of ABI Prism 7000 (Applied Biosystems, Darmstadt, Germany) following the manufacturers' instructions and by using SYBR Green Reaction Master Mix (ABI Prism; Applied Biosystems) and the primers listed in Table 1. All primers were synthesized by Invitrogen. In every RNA sample, $\beta$-actin mRNA was measured as the housekeeping gene (ubiquitin $C$ was also measured with very similar results). Values were then compared with those obtained by using the control-RNA obtained from sham-irradiated rats from each animal series. The results were normalized to the housekeeping gene and fold change expression was calculated by using threshold cycle $(\mathrm{Ct})$ values. During a real-time RT-PCR, the number of cycles when expression of any specific gene under study reaches a predetermined threshold of detection is known as the $\mathrm{Ct}$ value. The $\mathrm{Ct}$ value (threshold cycle) is defined as the fractional cycle number at which the fluorescence passes the fixed threshold. The higher the $\mathrm{Ct}$ value is for the specific gene at a given time, the lower the abundance is for the specific mRNA. For calculation of the relative changes, gene expression measured in sham-irradiated animals sacrificed at the same time points as irradiated animals was set at 1 .

For Northern blot analysis, total RNA (5 $\mu \mathrm{g} / \mathrm{lane})$ was size-fractionated by electrophoresis in $1 \%$ agarose-formaldehyde gels, transferred to nylon membranes (Amersham Pharmacia Biotech, Freiburg, Germany) by using the capillary transfer system, and cross-linked by UV light. Rat CXCL1 CDNA was generated by PCR from rat hepatic RNA with the primers listed in Table 1. Hybridization was performed at $68^{\circ} \mathrm{C}$ for 2 hours with randomprimed $\alpha^{32}$ P-labeled dCTP labeled cDNA probes for $\mathrm{KC} /$ CXCL1 (Amersham Pharmacia Biotech). PCR products were visualized by gel electrophoresis ( $1 \%$ agarose) and ethidium-bromide staining. 
Table 1. Rat Primer Sequences Used in This Study

\begin{tabular}{|c|c|c|}
\hline Primer & Forward & Reverse \\
\hline MIP-2/CXCL2 & $5^{\prime}$-ATCCAGAGCTTGACGGTGAC-3' & 5'-AGGTACGATCCAGGCTTCCT-3' \\
\hline CXCR2 & $5^{\prime}$-CCAAGCTGATCAAGGAGACC-3' & 5'-GGGGTTAAGACAGCTGTGGA-3' \\
\hline LIX/CXCL5 & 5'-CTCAAGCTGCTCCTTTCTCG-3' & 5'-GCGATCATTTTGGGGTTAAT-3' \\
\hline KC/CXCL1 & 5'-GGCAGGGATTCACTTCAAGA-3' & 5'-GCCATCGGTGCAATCTATCT-3' \\
\hline MCP-1/CCL2 & $5^{\prime}$-AGGCAGATGCAGTTAATGCCC-3' & 5'-ACACCTGCTGCTGGTGATTCTC-3' \\
\hline MCP-3/CCL7 & 5'-GCATGGAAGTCTGTGCTGAA-3' & 5'-CCGTTCCTACCCCTTAGGAC-3' \\
\hline CCR2 & 5'-СTTGTGGCCCTTATTTTCCA-3' & $5^{\prime}-$ AGATGAGCCTCACAGCCCTA-3' \\
\hline NE & 5'-CTTTGAGAACGGCTTTGACC-3' & $5^{\prime}$-CACATTGAGCTCTTGGAGCA-3' \\
\hline PECAM-1 & 5'-TCAGCTGCCAGTCAGTAAATGG-3' & 5'-TCTGGAAGTTGCTCTTTGCTCTT-3' \\
\hline IL-8/CXCL8 & $5^{\prime}$-CCCCCATGGTTCAGAAGATTG-3' & 5'-TTGTCAGAAGCCAGCGTTCAC-3' \\
\hline IFN- $\gamma$ & $5^{\prime}$-GAACTGGCAAAAGGACGGTA-3' & 5'-CTGATGGCCTGGTTGTCTTT-3' \\
\hline IP-10/CXCL10 & 5'-CTGTCGTTCTCTGCCTCGTG-3' & 5'-GGATCCCTTGAGTCCCACTCA-3' \\
\hline $\mathrm{IL}-1 \beta$ & 5'-TACCTATGTCTTGCCCGTGGAG-3' & 5'-ATCATCCCACGAGTCACAGAGG-3' \\
\hline IL-6 & 5'-GTCAACTCCATCTGCCCTTCAG-3' & 5'-GGCAGTGGCTGTCAACAACAT-3' \\
\hline$\beta$-actin & 5'-ACCACCATGTACCCAGGCATT-3' & $5^{\prime}$-CCACACAGAGTACTTGCGCTCA-3' \\
\hline Ubiquitin C & $5^{\prime}$-CACCAAGAAGGTCAAACAGGAA-3' & $5^{\prime}$-AAGACACCTCCCCATCAAACC-3' \\
\hline
\end{tabular}

\section{Laser Capture Microdissection}

Liver sections were dissected from frozen tissues (three for each time point and three regions per section) of rat liver after irradiation. The structure of the portal area and liver parenchyma were microdissected by laser capture microdissection (Carl Zeiss Jena, Germany) according to the previously described protocol. ${ }^{28}$ Briefly, $10-\mu \mathrm{m}$-thick liver cryostat sections were cut and placed on RNase free slides. Liver sections were fixed by using different concentrations of ethanol and stained shortly by RNase free hematoxylin. Fixed sections were immediately used for laser capture microdissection by using the UV laserbased PALM MicroBeam system (PALM Microlaser Technologies AG, Bernried, Germany). After the desired cell areas were selected microscopically, a pulsed 337-nm UV laser controlled by the PALM Robo Software automatically cut around the selected area and then catapulted it into a collection device. For RNA analysis, the cap of a $500-\mu l$ microfuge tube was filled with $20 \mu \mathrm{l}$ of mineral oil for sample collection. RNA was isolated by using an Invisorb RNA kit 1 (Invitek, Berlin, Germany) as per instructions. The cDNA and PCR were performed as described above.

\section{Isolation of Liver Parenchymal and Nonparenchymal Cells and in Vitro Treatment (Irradiation)}

\section{Parenchymal Cell Isolation and Cell Culture Conditions}

Liver parenchymal (hepatocytes) cells were isolated from normal animals according to protocol described previously. ${ }^{29}$ The purity of the isolated cell populations was determined by phase-contrast microscopy and by immunocytochemistry by using antibodies against laminin or glial fibrillary acidic protein to identify stellate cells (both from Sigma) or ED1 and ED2 (gift from C. Dijkstra) for macrophages. The cells were incubated at $37^{\circ} \mathrm{C}$ in a 95\% air and 5\% $\mathrm{CO}_{2}$ atmosphere. Dulbecco's modified Eagle's medium (Biochrom, Berlin, Germany) was sup- plemented with 10\% FCS (PAA, Cölbe, Germany), 1 $\mathrm{nmol} / \mathrm{L}$ insulin (Roche), and $100 \mathrm{nmol} / \mathrm{L}$ dexamethasone (Sigma). On the first day after isolation, hepatocytes were irradiated (8 Gy) with $6 \mathrm{mV}$ photons at a dose rate of 2.4 Gy/min by using a Varian Clinac $600 \mathrm{C}$ accelerator as described previously. ${ }^{24}$

\section{Liver Nonparenchymal Cells Isolation}

Liver (myo)fibroblasts isolation and cell culture conditions. Rat liver (myo)fibroblasts (LMFs) were isolated and cultured as described previously. ${ }^{26}$ In brief, cells were cultured in Dulbecco's modified Eagle's medium (Biochrom) supplemented with 15\% FCS, $100 \mathrm{U} / \mathrm{ml}$ penicillin, 100 $\mu \mathrm{g} / \mathrm{ml}$ streptomycin, and $1 \%$ L-glutamine. The culture medium was replaced 2 days after plating and then every second day. The cultured cells were maintained at $37^{\circ} \mathrm{C}$ in a $5 \% \mathrm{CO}_{2}$ atmosphere with $100 \%$ humidity. Passage was performed when cells reached confluence, and cells were used 4 days after the first passage. Isolated LMFs were irradiated with $8 \mathrm{~Gy}$ as described above. RNA from all in vitro experiments was extracted 1, 3, 6, 12, and 24 hours after irradiation. Sham-irradiated cells served as controls in all experiments.

Kupffer cells isolation and cell culture conditions. Kupffer cells were isolated according to the method described before. ${ }^{30}$ Briefly, liver macrophages were plated by using 200,000 cells per milliliter of culture medium (M-199 [Biochrom] supplemented with $10 \%$ FCS [PAA]). Purity of the cell isolation was determined by ED1/ED2 staining. The medium was replaced 24 hours after isolation directly before irradiation. The cultured cells were maintained at $37^{\circ} \mathrm{C}$ in a $5 \% \mathrm{CO}_{2}$ atmosphere with $100 \%$ humidity. Isolated Kupffer cells were irradiated with 8 Gy as described above. RNA from all in vitro experiments was extracted 1 , $3,6,12$, and 24 hours after irradiation. Sham-irradiated cells served as controls in all experiments.

\section{Statistical Analysis}

The data were analyzed by using Graph Pad Prism 4 software (San Diego, CA). All experimental errors are 
A

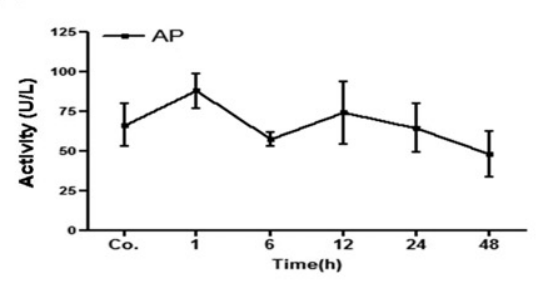

B

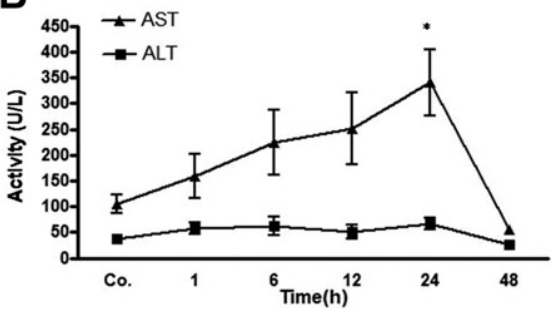

C

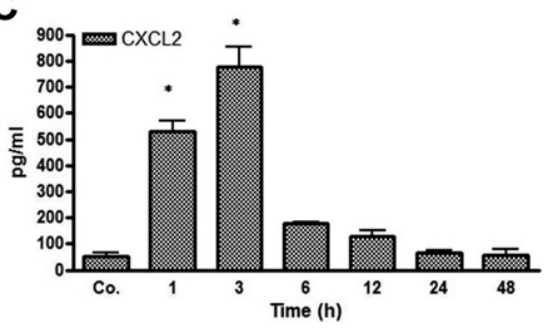

Figure 1. Serum enzyme levels in rats after liver irradiation. A: Alkaline phosphatase (AP) serum level was elevated after 1 hour but decreased thereafter. B: ALT was only slightly increased up to 24 hours after irradiation, whereas AST serum level continuously increased up to 24 hours after irradiation. AST increased significantly to its maximum at 24 hours in comparison with sham-irradiated controls. C: MIP-2/CXCL2-peptide levels in serum of irradiated rats compared with controls (sham-irradiated) are shown. Values on $y$ axis are serum concentration values of CXCL2 measured with enzyme-linked immunosorbent assay. The increase in serum levels 1 to 3 hours after irradiation was statistically significant. These results are representative of three animal series (statistically significant at ${ }^{*} P<0.05 ;$ mean \pm SEM)

shown as SEM. Statistical significance was calculated by one-way analysis of variance and Dunnett post hoc test. Significance was accepted at $P<0.05$.

\section{Results}

\section{Changes of Liver Enzymes and of MIP-2/CXCL2 Serum Levels in Irradiated Rats}

The alkaline phosphatase serum level was elevated above control values 1 hour after $\gamma$ irradiation of rat liver (Figure 1A). It returned to baseline after 6 hours, and no remarkable change was observed thereafter. Serum activity of AST was found to be elevated at 1 hour and reached a peak at 24 hours after irradiation. The increase at 24 hours was found to be statistically significant by Student's $t$-test analysis and over the whole-time-course by one-way analysis of variance $(P<0.0004)$. ALT serum levels remained increased and above control values for 24 hours during the experiment, but the changes were not significant (Figure 1B).

A significantly early rise (1 to 3 hours) of CXCL2 was measureable in the serum after irradiation as compared with the controls. Maximum CXCL2 concentra- tion was found (up to $774 \pm 80 \mathrm{pg} / \mathrm{ml} ; P<0.05$ ) at 3 hours after irradiation, followed by a quick decrease thereafter (Figure 1C).

\section{Immunohistochemical Detection of Neutrophil Granulocytes and Macrophages in the Irradiated Rat Liver}

By indirect immunohistochemical labeling (antibody against neutrophil elastase), it was possible to detect an early increase in the number of neutrophil granulocytes around the portal vessel of the rat liver after irradiation. Accumulation of $\mathrm{NE}^{+}$cells was visible at 1 hour and reached a maximum at 3 to 6 hours $(60.2 \pm 16.8$; Figure 2, A-C; Supplemental Figure S1, see http://ajp.amjpathol. org). At the same time, an increase (7.2 \pm 2.3 -fold at 6 hours) of NE gene expression at RNA level was also detected by RT-PCR analysis (Figure 2D). The number of positive cells decreased at later time points (12 and 24 hours). Very few $\mathrm{NE}^{+}$cells were observed in the parenchyma and central area of both irradiated and control livers.
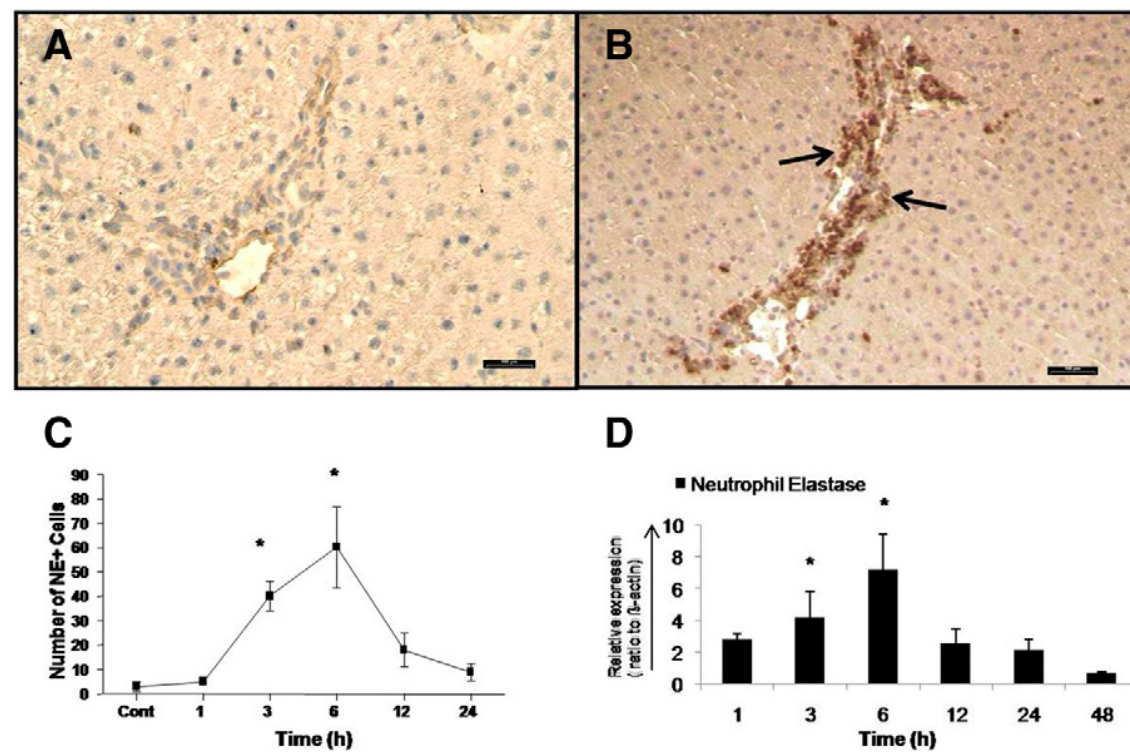

D

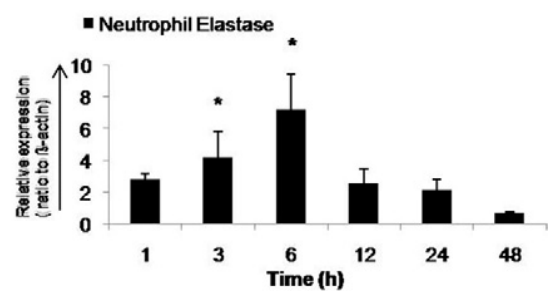

Figure 2. Indirect immunodetection of neutrophil elastase in sections of sham-irradiated rat liver (A) and 6 hours after irradiation $(\mathbf{B})$. Sections were stained with an antibody directed against neutrophil elastase followed by peroxidase staining (arrows indicate the $\mathrm{NE}^{+}$granulocytes in the portal field). C: $\mathrm{NE}^{+}$cells were also counted in portal field $(N=10)$ at different time points after rat liver irradiation. D: Fold change in hepatic mRNA expression of NE was measured by RT-PCR at different time points. Up-regulation of NE was detected after 1 hour and reached its maximum at 6 hours, after which it decreased following rat liver irradiation $(N=$ 3). Original magnification, $\times 200$. Scale bar $=$ $100 \mu \mathrm{m}$. Statistically significant at ${ }^{*} P<0.05$ $($ mean \pm SEM $)$ 

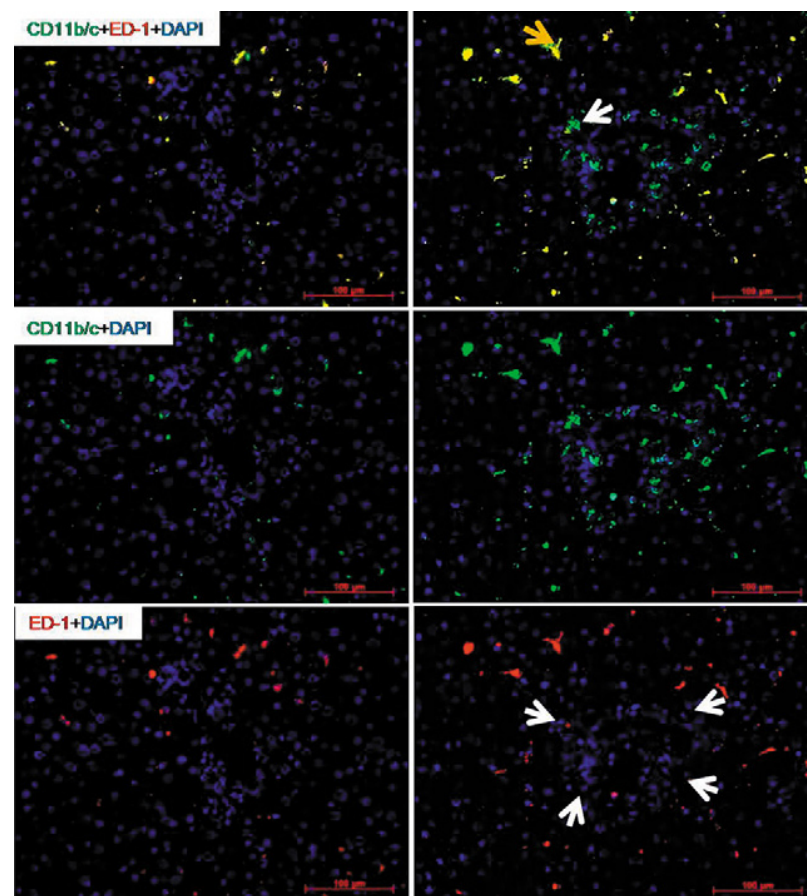

Figure 3. Double staining of liver sections with monoclonal antibody directed against $\mathrm{ED} 1$ (red) and monoclonal antibody against rat $\mathrm{CD} 11 \mathrm{~b} / \mathrm{c}$ (green) followed by fluorescence immunodetection in sections of rat liver after irradiation. Left: sham-irradiated animals; right: irradiated animals (6 hours). Yellow arrow indicates ED1 CD11b/c resident macrophages; white arrow indicates $\mathrm{ED} 1^{-} \mathrm{CD} 11 \mathrm{~b} / \mathrm{c}^{+}$recruited neutrophils. Upper: double staining; middle: CD11b/c staining; lower: ED1 staining (arrowheads indicate the portal area). Results represent mean value of three animals and six slides per time point. Original magnification, $\times 200$. Scale bar $=100 \mu \mathrm{m}$.

\section{Identification of Recruited Inflammatory Cells by Immunoflourescence Double Staining}

Similar to the results obtained with the elastase antibody, by double staining using CD11b/c and ED1 antibodies, a fast and early (3 to 6 hours) accumulation of CD11b/c ${ }^{+}$ but ED1- cells around the portal vessels was observed after irradiation of the rat liver. The $\mathrm{CD} 11 \mathrm{~b} / \mathrm{c}^{+}$cells started accumulating after 1 hour of irradiation, and this increase was only observed around the portal vessels (Figure 3). The number of CD $11 \mathrm{~b} / \mathrm{c}^{+}$cells decreased at later time points (12 and 24 hours) in the portal area. The double staining also showed $\mathrm{CD} 11 \mathrm{~b} / \mathrm{c}^{+}$and $\mathrm{ED} 1^{+}$cells in parenchyma (Kupffer cells; Figure 3), but no increase of $\mathrm{ED} 1^{+}$and $\mathrm{CD} 11 \mathrm{~b} / \mathrm{c}^{+}$cells was observed in the liver parenchyma at any time point after irradiation as compared with sham-irradiated controls. Compared with the results obtained with the CD11b/c antibody, no significant change was observed in the number of tissue phagocytes when the antibody against ED2 was used (Figure 4, A-D). These results were confirmed by counting the cells around the portal area (Figure 4, E and F). The tight relationship between the neutrophils and the vessels of the portal area was further underlined by the double staining using antibodies against CD11b/c and SMA (Figure 5, A and B). Furthermore, by using antibodies against $\mathrm{CD} 11 \mathrm{~b} / \mathrm{c}$ and against Thy-1 (double staining), Thy $-1^{+}$cells were observed not only in the wall of portal vessels but also located within the portal tracts adjacent
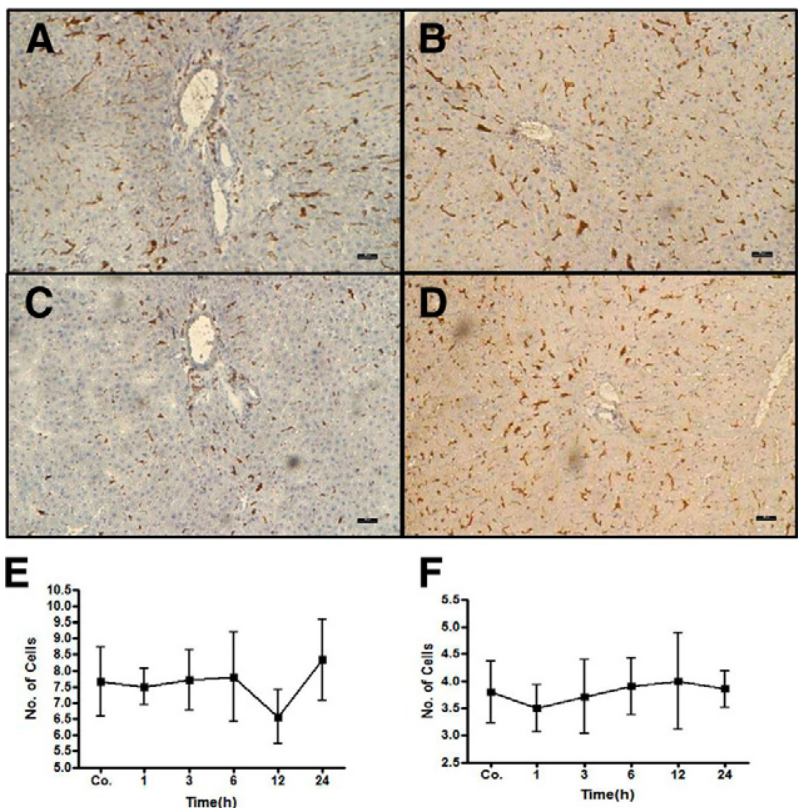

Figure 4. ED 1 and $\mathrm{ED} 2^{+}$cells in rat liver after irradiation. A: sham-irradiated ED1 cells $(\mathbf{C}) 6$ hours after treatment. B: sham-irradiated ED2 cells (D) 6 hours after treatment. ED ${ }^{+}(\mathbf{E})$ and $\mathrm{ED}^{+}(\mathbf{F})$ cells were also counted and no significant difference was observed in portal vessels at different time points after rat liver irradiation. Results represent mean value of three animals and six slides per time point. Original magnification, $\times 100$. Scale bar $=$ $100 \mu \mathrm{m}$.

to the wall of the portal vein and of the hepatic artery. Thy $-1^{+}$cells were showed in close contact to newly re-

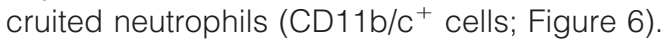

\section{Immunohistochemical Detection of MCP-1/CCL2 in the Irradiated Rat Liver}

By using an antiserum against MCP-1/CCL2, immune-reactivity of CCL2 was detected in the portal vessel walls and on some cells of portal area of rat liver with a peak 3 hours after irradiation. CCL2 expression was progressively decreased thereafter but detectable up to 24 hours (Figure 7, A-C; Supplemental Figure S2, see http://aip.amipathol.org). Increased expression of $\mathrm{CCL}_{2}{ }^{+}$cells was visible at 1 hour and reached a maximum at 3 hours (12.1 \pm 1.7 ; Figure 7D).

\section{Changes in Gene Expression of Chemokines and of Chemokines-Receptors in Irradiated Rat Liver}

CXCL1, CXCL2, and CXCL5 showed up-regulation after 1 hour, reaching their maximum CXCL1 (308.9 \pm 28.8fold), CXCL2 (61.4 \pm 5.3-fold), and CXCL5 (52.5 \pm 11.47-fold) 3 hours after irradiation (Figure 8A). We confirmed the induction of CXCL2 by PCR analysis where a clear difference was observed after liver irradiation as compared with sham-irradiated control (Figure 8B). Additionally, peak gene expression of CXCL1 (at 3 hours) was observed by RT-PCR and confirmed by Northern blot analysis (Figure 8C; Supplemental Figure S3 see http:// ajp.amjpathol.org). CXCL1, CXCL2, and CXCL5 gene ex- 

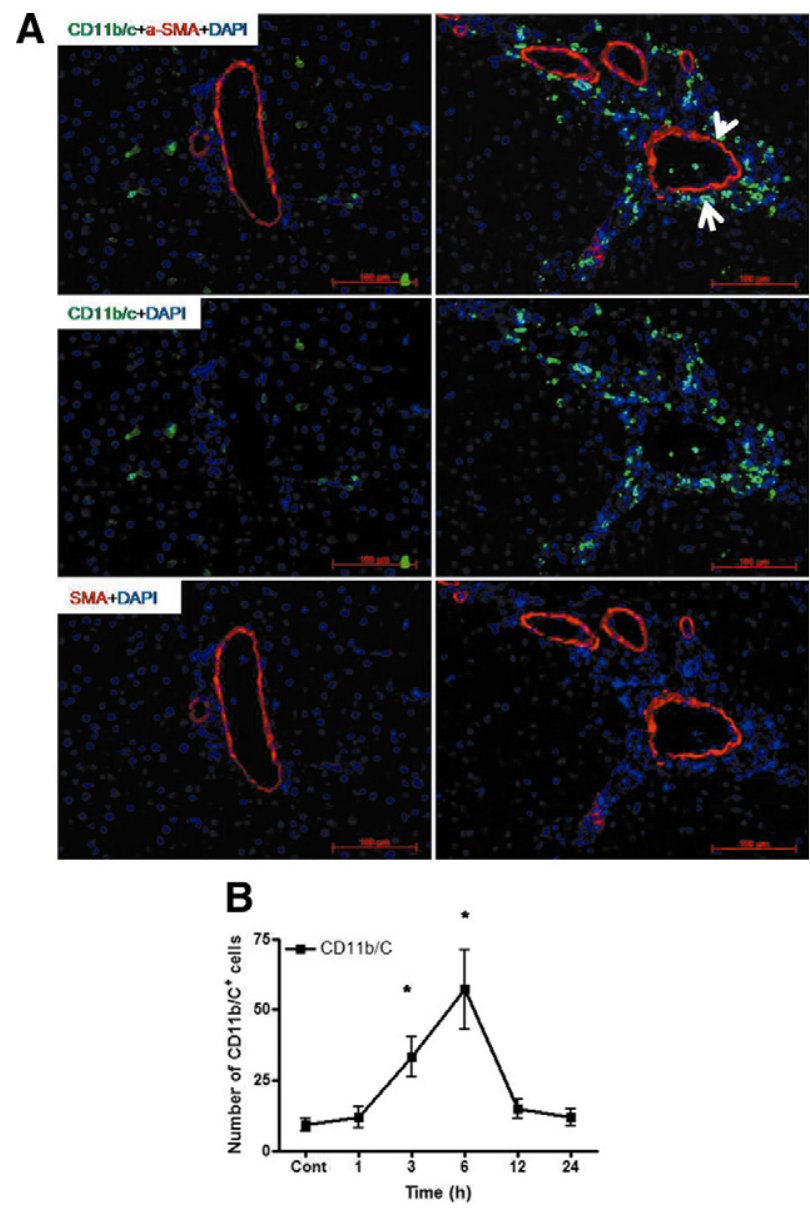

Figure 5. A: Double staining of liver sections with monoclonal antibody directed against SMA (red) and monoclonal antibody against CD11b/c (green) followed by fluorescence immunodetection in sections of rat liver. Left: shamirradiated animals; right: irradiated animals ( 6 hours). The arrow indicates the recruited neutrophils around the portal vessels, and the arrowhead indicates the (myo)fibroblasts $\left(\mathrm{SMA}^{+}\right.$) around the portal vessel. Upper: double staining; middle: $\mathrm{CD} 11 \mathrm{~b} / \mathrm{c}$ staining; lower: SMA staining. B: $\mathrm{CD} 11 \mathrm{~b} / \mathrm{c}^{+}$cells were also counted in the portal field $(N=10)$ at different time points after rat liver irradiation $(N=3)$. Original magnification, $\times 200$. Scale bar $=100 \mu \mathrm{m}$. Statistically significant at ${ }^{*} P<0.05$ (mean \pm SEM).

pression decreased progressively after 3 hours but remained higher than sham controls until 48 hours after rat liver irradiation. Parallel to the increase of granulocyte number around the portal vessel, CXCR2 transcripts also increased (24.4 \pm 5.6-fold) to a maximum at 3 hours after rat liver irradiation (Figure $8 \mathrm{~A}$ ).

MCP-1/CCL2 and MCP-3/CCL7 gene expression showed maximum up-regulation at 1 hour with a statistically significant increase of gene expression level up to 6 hours. However, gene expression of CC-chemokines receptor CCR2 did not show any change at early time points; down-regulation was seen at later time points (12 to 48 hours) after rat liver irradiation (Figure 9).

\section{Changes in Gene Expression of Chemokines in Microdissected Irradiated Rat Liver Sections (Portal and Parenchymal Area)}

Nine portal fields and nine parenchymal regions (three per liver section) per time point were microdissected

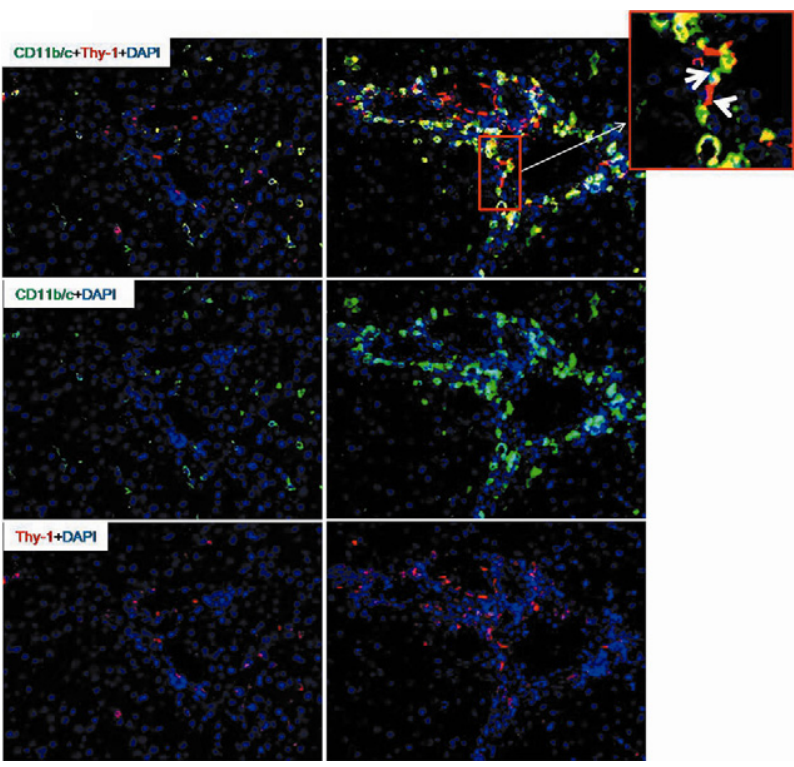

Figure 6. Double staining of liver sections with monoclonal antibody directed against Thy-1 (red) and monoclonal antibody against CD11b/c (green) and with labeled secondary antibodies of rat liver. Left: shamirradiated animals; right: irradiated animals (6 hours). Upper: double staining; middle: CD11b/c staining; lower: Thy-1 staining. Upper right small panel indicates the periportal localization of neutrophils between and around the (myo)fibroblasts $\left(\mathrm{Thy}^{-} \mathrm{1}^{+}\right.$). The arrow indicates the recruited neutrophils around the portal vessels, and the arrowhead indicates (myo)fibroblasts tightly connected with neutrophils. Results represent mean value of three animals and six slides per time point. Original magnification, $\times 200$. Scale bar $=100 \mu \mathrm{m}$.

and pooled. RNA was extracted and PCR was performed. The PCR protocol was optimized by varying the number of cycles and annealing temperature. Forty cycles of all other studied genes and 50 for platelet endothelial adhesion molecules (PECAM) and NE were taken as standard for PCR analysis. MCP-1/CCL2 and CXCL1 showed their maximum up-regulation at 1 hour. On the other hand, CXCL8 and receptor CXCR2 was also up-regulated at 1 hour but reached its peak 3 hours after rat liver irradiation in microdissected cells of the portal area. In contrast, no obvious change was observed in MCP-1/CCL2 gene expression in microdissected parenchymal tissue. On the contrary, strong up-regulation of CXCL1 gene expression was observed in the parenchyma with a maximum at 3 hours after irradiation. Furthermore, CXCR2 was only detectable in control-sham irradiated microdissected parenchymal tissue. NE gene expression increased with time and reached its peak at 6 hours in the microdissected portal area cells. However, in contrast, NE gene expression was not detectable in parenchymal cells. No obvious change of gene expression of CCR2 in portal as well as parenchymal tissue was observed at any time point. PECAM-1 was used as positive control to compare chemokines gene expression. No change in PECAM-1 gene expression was detected in any of the regions after irradiation (Figure 10; Supplemental Figure S4, a-d, see http://ajp.amjpathol.org). 


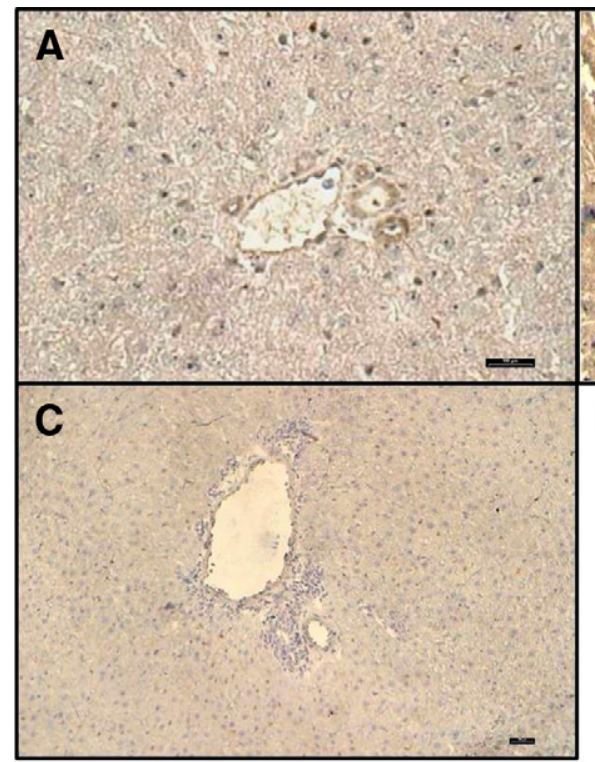

Portal area

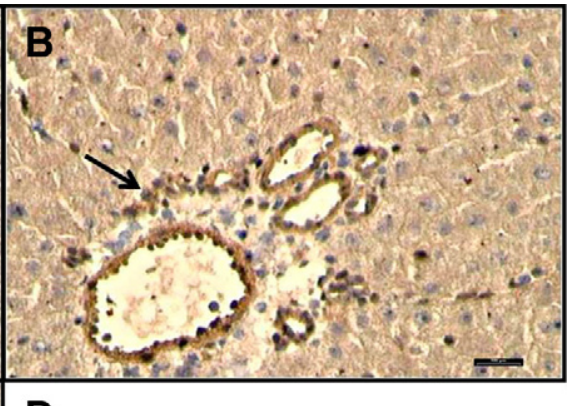

D

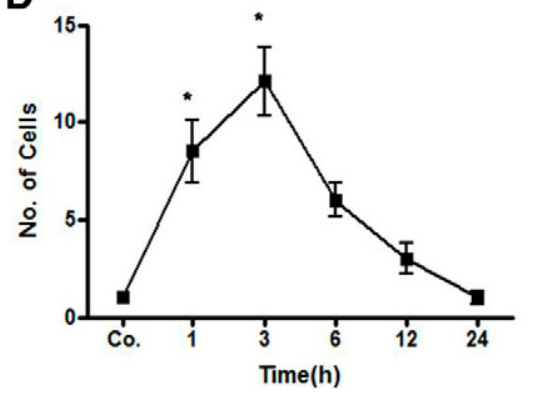

Figure 7. Immunodetection of MCP-1/CCL2 in sham-irradiated sections (A) and 3 hours after irradiation (B). Sections were stained with a goat polyclonal antiserum directed against CCL2 followed by peroxidase staining. Increased expression of CCL2 was observed in the walls of the portal vessel and on some cells of the portal area (arrow). CCL2 ${ }^{+}$cells accumulated around the vessel with a peak at 3 hours as compared with sham-irradiated controls (original magnification, $\times 200$; scale bar, $100 \mu \mathrm{m}$ ). C: Negative control was performed by using only secondary antibody against goat immunoglobulin followed by peroxidase staining (original magnification, $\times 100$; scale bar, $100 \mu \mathrm{m})$. D: Counted CCL $2^{+}$ cells in and around the portal field $(N=10)$. Results represent mean value of three animals and six slides per time point. Statistically significant at ${ }^{*} P<0.05($ mean \pm SEM $)$

\section{Influence of the Intraperitoneally Administered Monoclonal Antibody Against MCP-1/CCL2 on Hepatic Gene Expression After $\gamma$-Irradiation}

We next asked whether CCL2 is essential for periportal inflammation. Immunohistology revealed no significant change of portal inflammation 3 to 6 hours after (two rats) administration with CCL2-specific antibody and irradiation (group 3) as compared with animals treated with a

\section{A CXC-chemokines}

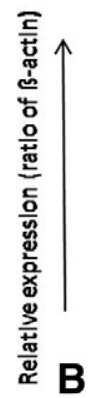
-CXCL1 $\square$ CXCL2 $\square$ CXCL5 $\square$ CXCR2

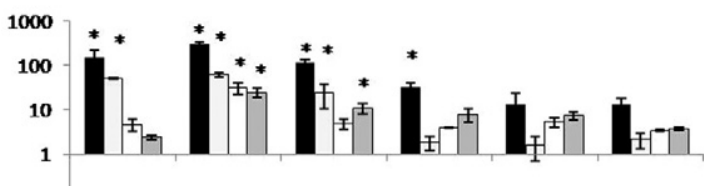
o.<smiles>[13CH3]</smiles>

3

6
Time (h)

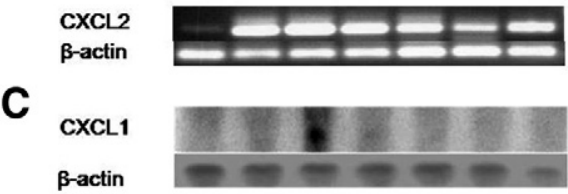

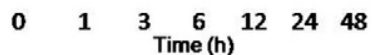

Figure 8. Fold change of mRNA expression of CXC-chemokines (CXCL1 CXCL2, and CXCL5) and their receptor CXCR2 in irradiated liver at different time points related to sham-irradiated controls. A: Maximum up-regulation of CXCL1, CXCL2, and CXCL5 gene expression is detectable at 3 hours and that of their receptor CXCR2 also at 3 hours after rat liver irradiation by RT-PCR. B: CXCL2 PCR shows the peak up-regulation at 3 hours. RT-PCR was normalized by using two housekeeping genes: $\beta$-actin and ubiquitin C. C: Northern blot analysis of CXCL1 showed maximum induction at 3 hours after rat liver irradiation. Results represent mean \pm SEM values of three experiments (in duplicate) compared with sham-irradiated controls for each time point ( $* P<0.05$, analyzed by one-way analysis of variance). single-dose of irradiation (group 1) as determined by counting the number of neutorphils in the portal area, measuring neutrophil elastase, CXCR2, and ED1 gene expression by RT-PCR (data not shown). In contrast, a clear down-regulation of IFN- $\gamma$ gene expression was observed only in irradiated rat livers (group 1). Induction of gene expression of IFN- $\gamma(4.7 \pm 0.9$-fold $)$ was detected at 3 hours by RT-PCR in rats treated with MCP-1/CCL2 antibody (group 3). Further, a significantly higher induction of IP-10/CXCL10 (inducible by IFN- $\gamma$ ) gene expression was also detected in group 3 compared with group 1 at 3 hours (Figure 11, A and B). The administration of antibody against MCP-1 did not affect the magnitude of up-regulation of MCP-1 gene expression induced in the liver by $\gamma$-irradiation (data not shown).

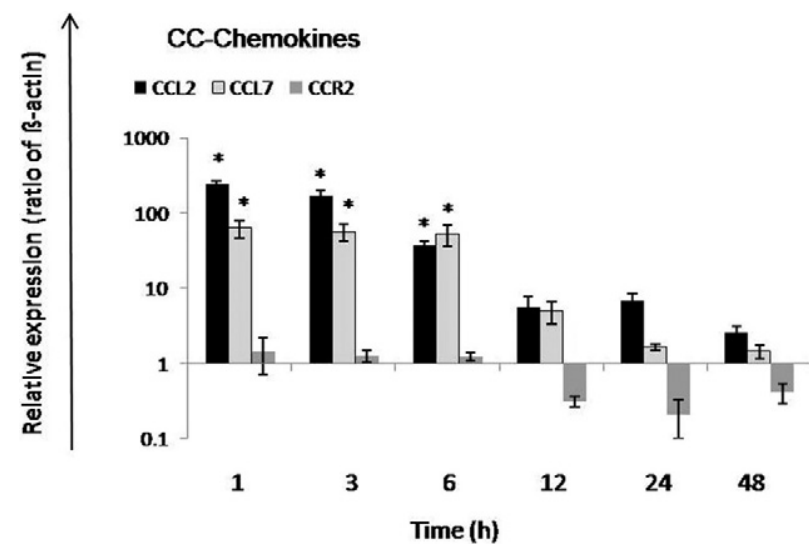

Figure 9. Fold change of mRNA expression of CC-chemokines in irradiated rat liver. MCP-1/CCL2 and MCP-3/CCL7 gene expression reached its peak after at 1 hour. CCR2 was down-regulated with maximum at 24 hours after irradiation. RT-PCR was normalized by using two housekeeping genes: $\beta$-actin and ubiquitin $C$. Results represent mean \pm SEM values of three experiments (in duplicate) compared with sham-irradiated controls for each time point ( ${ }^{*} P<0.05$, analyzed by one-way analysis of variance). 
Liwer Portal area

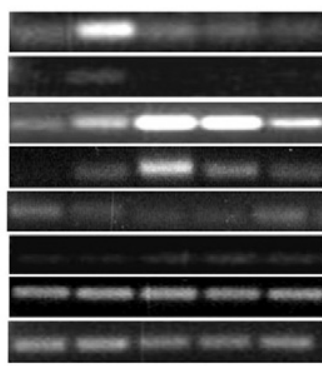

$\begin{array}{lllll}0 & 1 & 3 & 6 & 12\end{array}$
Liver Parenchyma tissue

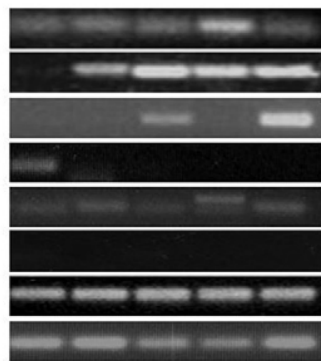

Time (h)

Figure 10. PCR analysis of total RNA extracted from microdissected liver tissue from portal areas and liver parenchyma. Oligonucleotides specific for different genes were used. Liver tissues taken at different time points after irradiation were used for microdissection. The size of the PCR product was analyzed by agarose (1\%) gel-electrophoresis (UV light picture)

\section{Change in Gene Expression of Chemokines and Cytokines in Irradiated Parenchymal and Nonparenchymal Liver Cells}

We investigated gene expression of chemokines in cultured liver parenchymal (hepatocytes) and nonparenchymal (LMFs and liver macrophages) cells at different time points after irradiation (1, 3, 6, 12, and 24 hours) compared with sham-irradiated cells. After preliminary experiments in which different radiation doses were used $(2,8$, and 25 Gy), we chose 8 Gy because no greater effect was observed by using 25 Gy. Up-regulation of CXCL2 ( $3.3 \pm 0.56$-fold $)$ and CXCL5 (1.56 \pm 0.1 -fold $)$ at 1 hour was detected in rat parenchymal cells after irradiation. MCP-1/CCL2 showed no obvious change after irradiation, but receptor CXCR2 (7.7 \pm 1.6 -fold) was up-regulated at 1 hour in irradiated hepatocytes. However, CXCL1 and receptor CCR2 showed quick down-regulation at 1 and 3 hours, respectively, with a further decrease up to 24 hours in irradiated hepatocytes (Figure 12, A and B). Both IL-1 $\beta$ and IL-6 were not detectable in nonirradiated and irradiated liver parenchymal cells.

Cultured LMFs constitutively express CCL2 and its expression is even stronger than in irradiated liver tissue. Furthermore, irradiation of LMFs was able to increase not only the MCP-1/CCL2 (5.7 \pm 1.7 -fold) gene expression, but also that of other chemokines and cytokines (IL-1 $\beta$ and IL-6).

A quick and early (1 hour) up-regulation of CXCL1 (4.8 \pm 0.42 -fold) and CXCL2 (3.2 \pm 0.44 -fold) was found at RNA level in irradiated LMFs (8 Gy). Furthermore, up-regulation of CXCL5 (3.2 \pm 0.44 -fold) was also observed at 3 hours. CXCR2, CCR2 gene expression, was not detectable in the nonirradiated nor in irradiated LMFs (Figure 13, A-C).

Isolated Kupffer cells constitutively express CXCL1, CXCL2, CXCL5, CXCL8, and a low amount of CCL2, but no significant change in CXCL1, CXCL5, and CCL2 gene expression was observed after irradiation. However, a significant up-regulation of CXCL2 (2.94 \pm 0.7 -fold) and
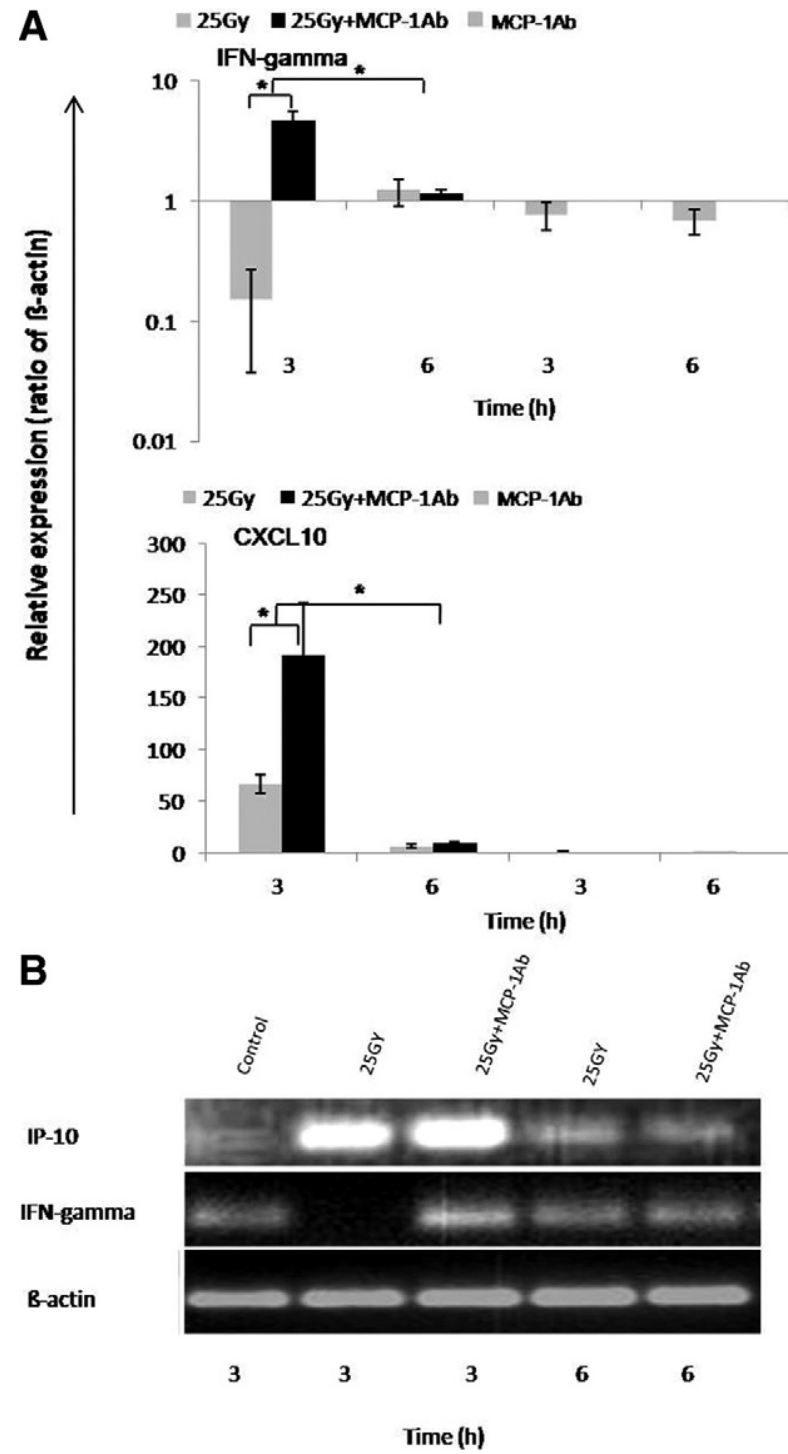

Figure 11. Influence of the intraperitoneally administered monoclonal antibody against MCP-1/CCL2 on hepatic gene expression after $\gamma$-irradiation. Fold change of mRNA expression of IFN- $\gamma$ and IP-10/CXCL10 in rat liver at different time points after irradiation. A: Down-regulation of gene expression of IFN- $\gamma$ in rat liver after a single dose irradiation was detected (upper), whereas up-regulation was detected 3 hours after irradiation in rat liver when a single dose of MCP-1/CCL2 antibody was administered. IP-10/CXCL10 was significantly up-regulated after irradiation compared with sham-irradiated controls. However, a significant further up-regulation was observed at 3 hours when a single dose of MCP-1/CCL2 antibody was administered before irradiation (lower). B: The results obtained by real-time PCR analysis (see above) were confirmed by agarose gel analysis of the PCR product. RT-PCR data shown as fold changes in mRNA expression were normalized with two housekeeping genes: $\beta$-actin and ubiquitin C of IFN- $\gamma$ and IP-10/CXCL10 at different time points related to sham-irradiated controls. Results represent the mean value of two experiments (in duplicate) and mean value \pm SEM are compared with sham-irradiated antibody-treated controls for each time point ( ${ }^{*} P<0.05$, analyzed by one-way analysis of variance).

CXCL8 (2.72 \pm 0.54-fold) was found at 3 hours after irradiation. Furthermore, a significant down-regulation of CCR2 (2.77 \pm 0.14-fold) was observed after 12 hours. CXCR2 gene expression remained unchanged after irradiation in isolated Kupffer cells (Figure 14, A and B).

Although the fold increase in the amounts of specific mRNA gives an idea of the changes in expression of single genes induced by $\gamma$-irradiation in liver tissue and 
A cxc-chemokines

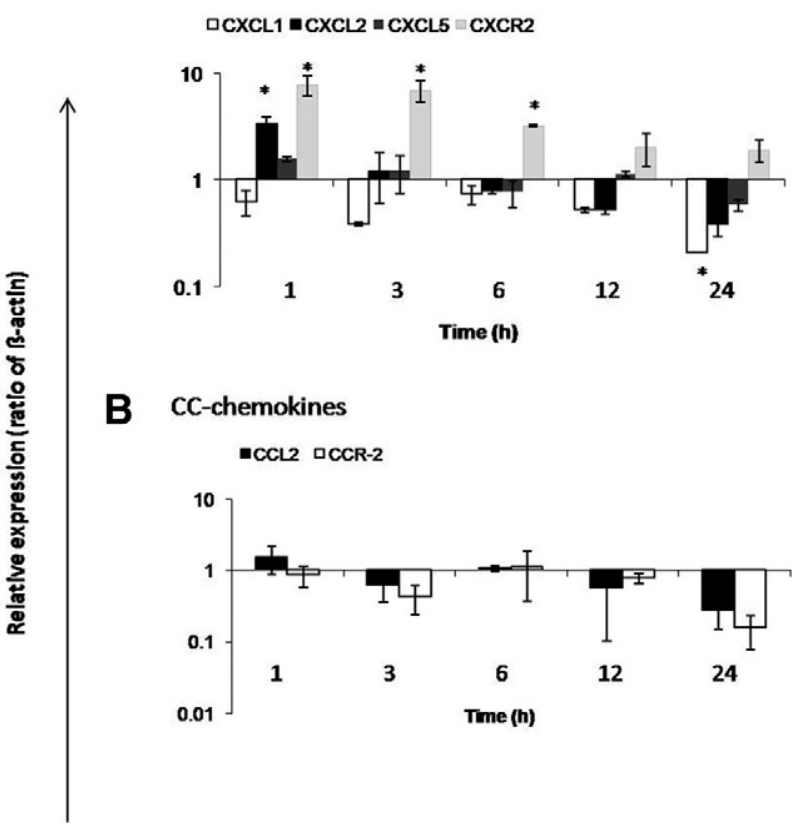

Figure 12. Fold change of mRNA expression of CXC-chemokines, CCchemokines, and cytokines at different time points in irradiated hepatocytes (8 Gy) related to sham-irradiated controls. A: Maximum up-regulation of CXCL2 and receptor CXCR2 gene expression was detectable at 1 hour by RT-PCR. CXCL1 and CXCL5 were down-regulated with the maximum at 24 hours in irradiated hepatocytes. B: MCP-1/CCL2 and receptor CCR2 gene expression maximum down-regulation was detectable at 12 hours. Cytokine (IL- $1 \beta$ nor IL-6) was detected in neither the nonirradiated nor in irradiated hepatocytes. RT-PCR data shown as fold changes in mRNA expression were normalized with two housekeeping genes: $\beta$-actin and ubiquitin $\mathrm{C}$. Results represent the mean value \pm SEM of three separate experiments (in duplicate) compared with sham-irradiated controls for each time point $\left({ }^{*} P<0.05\right.$ analyzed by one-way analysis of variance).

isolated cells, comparison of the Ct values provides an indirect indicator of relative gene expression of chemokines, chemokine receptors, and cytokines in liver tissue, hepatocytes, LMFs, and Kupffer cells before treatment, if started, and may provide additional insight (at least in part with regard to why the magnitude of changes induced by $\gamma$-irradiation in vivo cannot be achieved by irradiation of single-cell populations in vitro; Figure 15). In fact, it shows that the relative abundance of specific mRNA is lower in the liver tissue, but the kinetics of decrease of Ct values (increase of the amount of specific mRNA) is similar. CXCL5 and CXCL8 were constitutively expressed in isolated nonirradiated LMFs followed by Kupffer cells, hepatocytes, and liver tissue. In contrast, CXCL1 and CXCL2 showed stronger gene expression in nonirradiated Kupffer cells followed by hepatocytes in the case of CXCL1 and LMFs for CXCL2 and then to liver tissue. Constitutive expression of chemokines in liver tissue was low, whereas irradiated up-regulated chemokines gene expression was about 100-fold in liver tissue, and up-regulation in LMFs was about 10-fold because of strong constitutively expressed genes in isolated cells. Compared with gene expression in sham-irradiated livers, CXCL1 gene expression was higher in nonirradiated $(676 \pm 65.2$-fold $)$ and 3 hours $(668 \pm 83.1$-fold $)$ after irradiation of Kupffer cells, nonirradiated (35 \pm 5.2 -fold)
A CXC-chemokines

-CXCL1 $₫$ CXCL2 $\square$ CXC15 CXC18

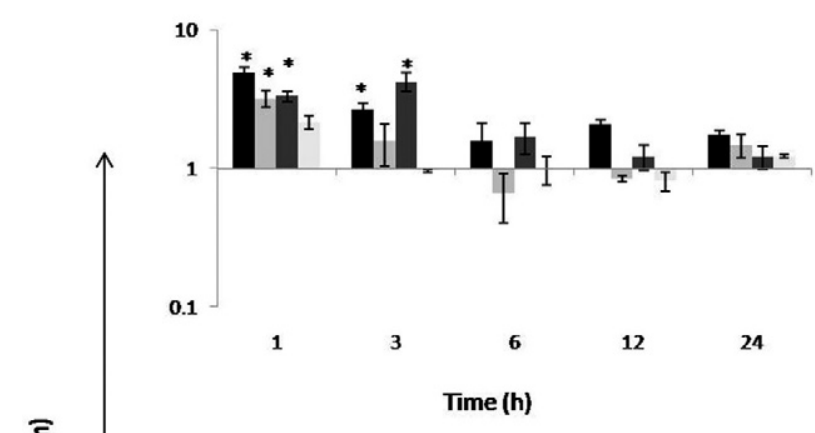

B CC-chemokines

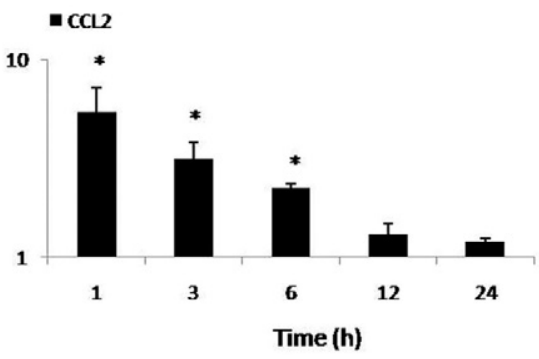

C Cytokines

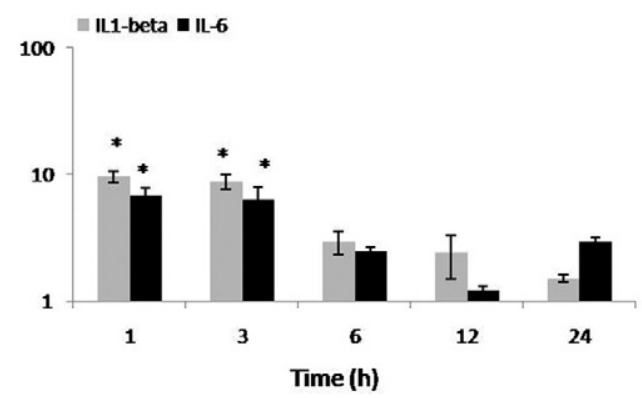

Figure 13. Fold change of mRNA expression of CXC-chemokines, CCchemokines, and cytokines at different time points in irradiated (myo)fibroblasts (LMFs; 8 Gy) related to sham-irradiated controls. A: Maximum upregulation of CXCL1 and CXCL2 gene expression was detectable at 1 hour. CXCL5 was up-regulated with maximum at 3 hours in irradiated LMFs. B: MCP-1/CCL2 gene expression was up-regulated with peak at 1 hour. Both receptors (CXCR2 and CCR2) were not detected in irradiated LMFs. C: Cytokines, IL-1 $\beta$ and IL-6, were early up-regulated with peak at 1 hour. RT-PCR data shown as fold changes in mRNA expression were normalized with two housekeeping genes: $\beta$-actin and ubiquitin C. Results represent mean value \pm SEM of three separate experiments (in duplicate) compared with sham-irradiated controls for each time point $\left({ }^{*} P<0.05\right.$, analyzed by one-way analysis of variance).

and 3 hours $(21 \pm 3.1$-fold) after irradiation of hepatocytes, and nonirradiated (11.5 \pm 2.2 -fold) and 3 hours $(33.4 \pm 7.1$-fold $)$ after irradiation in LMFs. Furthermore, CXCL2 expressed strongly in nonirradiated (11571 \pm 465-fold) and 3 hours (15862 \pm 683 .1-fold) after irradiation of Kupffer cells, nonirradiated (15 \pm 1.2 -fold) and 3 hours (29 \pm 3.1 -fold) after irradiation of hepatocytes, and nonirradiated (98 \pm 17 -fold) and 3 hours (565 \pm 97.1fold) after irradiation in LMFs. CXCL5 gene expression was also higher in nonirradiated ( $5 \pm 1.2$-fold) and 3 hours ( $9 \pm 3.1$-fold) after irradiation in hepatocytes, non- 
A cxc-chemokines

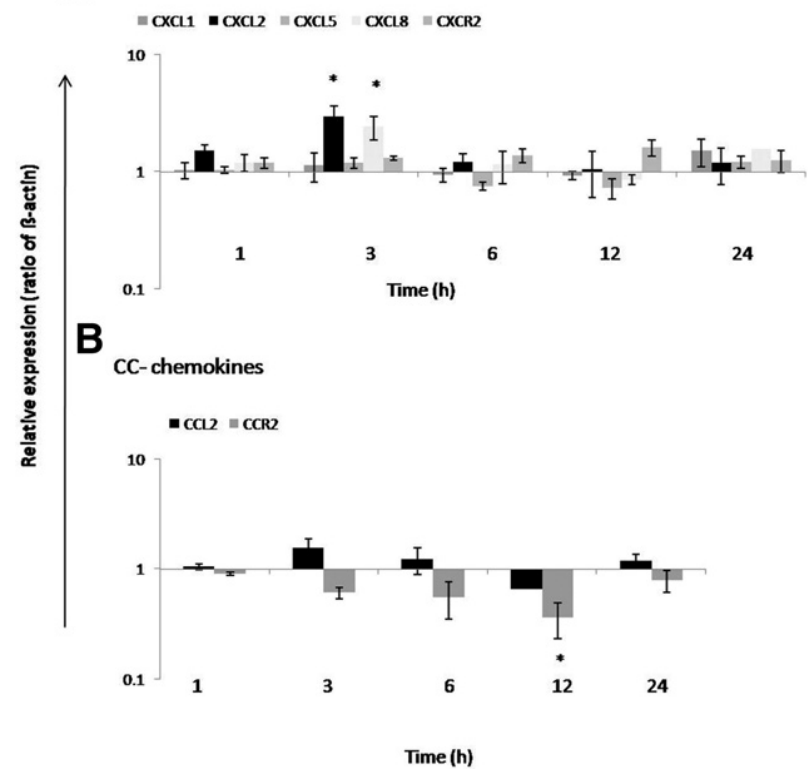

Figure 14. Fold change of mRNA expression of CXC-chemokines and CC-chemokines at different time points in irradiated Kupffer cells (8 Gy) related to sham-irradiated controls. A: Maximum up-regulation of CXCL2 and CXCL8 gene expression was detectable at 3 hours. No significant induction of CXCL1 and CXCL5 was observed in irradiated Kupffer cells. Gene expression of CXCR2 remained unchanged. B: However, receptor CCR2 was significantly down-regulated at 12 hours, but MCP-1/CCL2 showed no significant induction in Kupffer cells after irradiation (8 Gy). RT-PCR data shown as fold changes in mRNA expression were normalized with two housekeeping genes: $\beta$-actin and ubiquitin $C$. Results represent mean value \pm SEM of three separate experiments (in duplicate) compared with sham-irradiated controls for each time point ( ${ }^{*} P<0.05$, analyzed by one-way analysis of variance).

irradiated (65.5 \pm 8.2-fold) and 3 hours (668.4 \pm 64.6fold) after irradiation in LMFs, and nonirradiated (101.1 \pm 8 -fold) and 3 hours (118 \pm 13-fold) after irradiation of Kupffer cells compared with the sham-irradiated livers. In the same way, CXCL8 gene expression was higher in nonirradiated (118.6 \pm 9.2-fold) and 3 hours (76 \pm 12.1 fold) after irradiation in hepatocytes, nonirradiated (504.9 \pm 79.2-fold) and 3 hours (453.5 \pm 64.6-fold) after irradiation in LMFs, and nonirradiated (388.1 \pm 98 -fold) and 3 hours (873 \pm 138 -fold) after irradiation of Kupffer cells compared with the sham-irradiated livers. Constitutive expression of the CCL2 gene was the highest in nonirradiated LMFs (229 \pm 18-fold) followed by nonirradiated hepatocytes ( $2 \pm 0.18$-fold) compared with the Kupffer cells (nonirradiated: $0.9 \pm 0.2$-fold; 3 hours after irradiation: $1.4 \pm$ 0.4-fold) and sham-irradiated livers. CCL2 gene expression was also further increased in LMFs (982 \pm 78 -fold at 3 hours) and livers (Figure 9) after irradiation compared with the sham-irradiated livers, but no change was detected in irradiated hepatocytes. CXCR2 gene expression was higher in Kupffer cells than in hepatocytes and sham-irradiated liver tissue; similarly, strong gene expression of CCR2 was detected in isolated nonirradiated Kupffer cells, whereas expression of the same gene in hepatocytes and sham-irradiated liver tissue was low. Taken together, all three cell populations are able to express the same chemokine genes but at a different level, whereby CCL2 gene expression is the highest in (myo)fibroblasts and lowest in Kupffer cells.

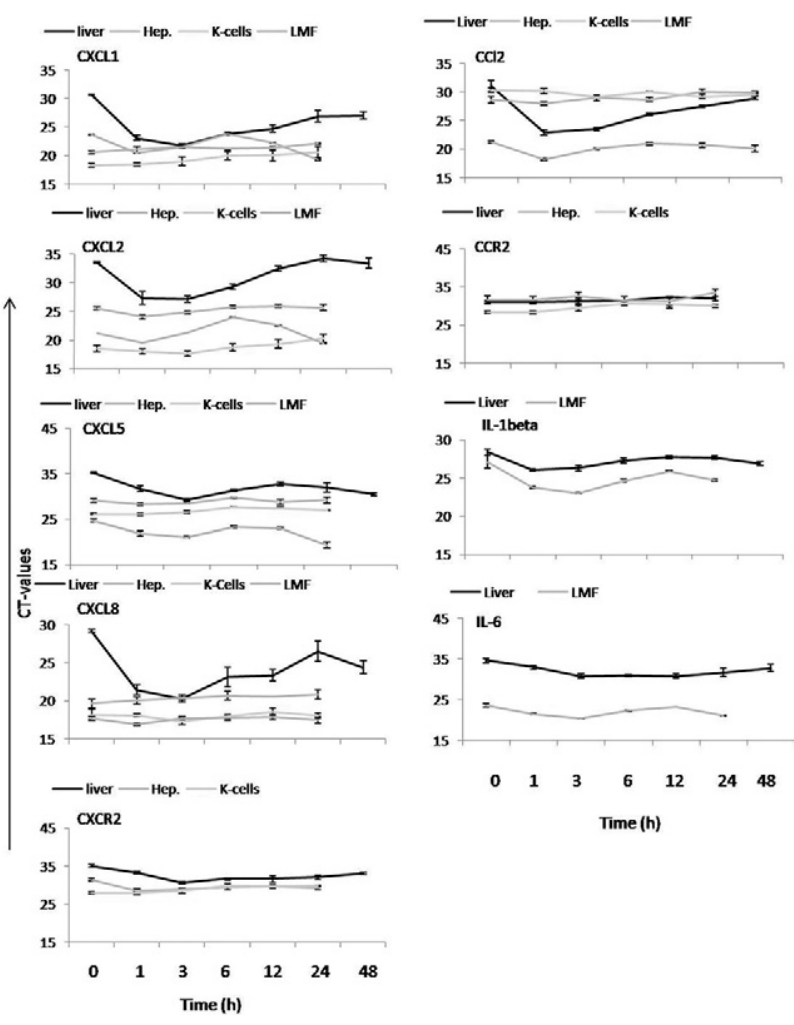

Figure 15. Comparison of Ct values of CXC-chemokines (CXCL1, CXCL2, CXCL5, and CXCL8), CC-chemokines (CCL2 and CCL7), receptors CXCR2 and CCR2, and cytokines (IL-1 $\beta$ and IL-6), respectively, in rat liver, hepatocytes, Kupffer cells, and liver (myo)fibroblasts after irradiation and sham-irradiated controls. Results were obtained by RT-PCR analysis of total RNA extracted from normal and irradiated livers and from isolated liver cells after $\gamma$-irradiation. Results represent three experiments (in duplicate) and mean \pm SEM values are shown for each time point.

Furthermore, their expression was further increased after irradiation in liver tissue (Figures 8 and 9) and LMFs (Figure 13) after irradiation but to a lesser extent in isolated hepatocytes and Kupffer cells (Figures 12 and 14).

LMFs also strongly express the cytokines: IL- $1 \beta$ with a 10-fold increase at 3 hours after irradiation. IL-6 was also strongly expressed in nonirradiated LMFs, and expression was further increased at 3 hours after irradiation. IL-1 $\beta$ and IL- 6 gene expression was not found in hepatocytes. Likewise, CXCR-2 and CCR2 were undetermined in nonirradiated and irradiated LMFs.

\section{Discussion}

Clinical and pathological studies revealed that radiation therapy can produce significant hepatic injury. Radiationinduced liver disease has been one of the most important treatment-related complications of hepatic irradiation. The liver toxicity pathomechanisms of radiotherapy are not clearly understood.

In this work, we found an increase of the liver enzymes in the serum of irradiated rats, but only the early increase of AST reached a significantly high level. At the same time, an increased serum level of CXCL2 was detectable, together with a brisk increase of CXC-chemokines (CXCL1, CXCL2, CXCL5, and CXCL8), CC-chemokines (MCP-1/ 
CCL2 and MCP-3/CCL7) of the CXCR2, and neutrophil elastase hepatic gene expression. A quick, early, and transient recruitment of leukocytes (neutrophil granulocytes) around the portal vessels was observed after a single high dose (25 Gy) of $\gamma$-irradiation. Interestingly, granulocytes were detectable only in the portal area between and around the liver (myo)fibroblasts (Thy- $1^{+}$ cells) but not along the sinusoids nor around the central vein. Furthermore, no increase of mononuclear phagocytes $\left(\mathrm{ED} 1^{+}\right.$and $\left.\mathrm{ED} 2^{+}\right)$was observed by immunohistochemistry at any time point after irradiation. Immunohistology and laser capture microdissection allowed us to localize an increase of MCP-1/CCL2 mRNA in the portal area but not in the parenchyma. A similar behavior could be detected for CXCL1, CXCL8, and neutrophil-elastase gene expression; CXCL1, however, was also strongly expressed in the liver parenchyma. Because immunohistology and laser capture microdissection experiment suggested that CCL2 could be of crucial importance for the recruitment of neutrophils into the portal area, we treated the animals with a monoclonal antibody against MCP-1/CCL2 intraperitoneally before irradiation was performed and sacrificed them at the time points at which the highest increase of neutrophils had been previously observed. Although some changes of gene expression were observed at the RNA level, mainly the increase of IFN- $\gamma$ and of one of its target genes, IP-10/CXCL10 gene expression, no change in the number of neutrophils recruited into the portal area was observed. Interestingly, one could speculate that the increase of IP-10/CXCL10 gene expression represents a compensation for the decrease of the CCL2 availability because, in fact, CXCL10 may participate in neutrophil recruitment. ${ }^{31}$

To address the question of the cellular source of the up-regulated chemokines gene expression within the portal field, we focused on (myo)fibroblasts, which are also known to be an important source of chemokines ${ }^{3,32}$ and cytokines like IL-6. ${ }^{3,33}$ This was also suggested by the positive staining of the portal structures with the antiMCP-1/CCL2 antibody. LMFs after the first passage showed a constitutive gene expression of the chemokines, which were found to be up-regulated in the whole liver and in the portal area after $\gamma$-irradiation. Irradiation of the cells further up-regulated gene expression of all of the chemokines studied and cytokines (IL-1 $\beta$ and IL-6).

Furthermore, because a few ED1 ${ }^{+}$and $\mathrm{ED}^{+}$cells (liver macrophages and Kupffer cells) are also present in the portal area, and Kupffer cells are known to express the gene of several chemokines, ${ }^{34,35}$ changes of chemokines gene expression after $\gamma$-irradiation were also studied in isolated liver macrophages. Experiments show that isolated liver macrophages constitutively express CXCL1 and CXCL2 and that this expression is stronger than what is observed in the other cell populations studied. Kupffer cells also strongly express CXCL5 and CXCL8. The constitutive expression of CCL2, however, is much lower than that observed in (myo)fibroblasts. Furthermore, $\gamma$-irradiation only slightly up-regulated CXCL2 and CXCL8 gene expression in isolated Kupffer cells, but no change was induced in CCL2 gene expression. This finding may explain why neutrophils recruitment only takes place in the portal area and may also support the hypothesis that mesenchymal cells of the sinusoidal wall (hepatic stellate cells) behave differently from the mesenchymal cells of the portal vessels and the portal area (Thy $-1^{+}$cells). ${ }^{36}$

Hepatocytes were studied because they represent the major source of parenchymal gene expression. Irradiation of hepatocytes, on the other hand, induced only an increase of CXCL2, again further supporting the assumption that (myo)fibroblasts could be the main target of irradiation and the main source of the factors responsible for the migration of neutrophils through the vessel wall. Endothelial cells may be of importance for adherence of inflammatory cells to the vessel wall because microvascular endothelial apoptosis represents the primary lesion in radiation damage. ${ }^{37}$ They may, however, play a minor role in transmigration of the same cells because in vitro irradiation of endothelial cells was not able to induce up-regulation of chemokines gene expression. ${ }^{38}$ ALT is known to be specific for liver damage. In the liver, ALT is localized solely in the cellular cytoplasm, whereas AST is in both cytosolic (20\% of total activity) but mostly mitochondrial (80\% of total activity). ${ }^{39}$ Although the recruited granulocytes (together with the $\gamma$-irradiation) could lead to the damage of a few periportal hepatocytes, the effect of the treatment could have an even stronger damaging impact on the numerous and large mitochondria of the hepatocytes and therefore induce a stronger release of AST than ALT.

In previous studies, we showed that irradiated livers were characterized histologically by a steatosis of periportal hepatocytes taking place between 24 and 48 hours after irradiation. ${ }^{22}$ On the other hand, $\gamma$-irradiation induced very early up-regulation of gene expression of several chemokines (eg, MCP-1/CCL2, MIP-3 $\alpha / C C L 20$, MIP-3 $\beta / C C L 19$, IL-8/CXCL8, MIG/CXCL9, IP-10/CXCL10, and ITAC/CXCL11) and other acute phase mediators (IL-1 $\beta$, IL-6, and tumor necrosis factor- $\alpha$ ); the exception was IFN- $\gamma$, which was down-regulated, though no gross inflammatory infiltrates were detected by light microscopy within the liver parenchyma. ${ }^{24}$ Additionally, gene expression of adhesion molecules mainly involved in inflammation was also up-regulated. ${ }^{40}$

Inflammatory cells have to undergo activation (priming) by inflammatory mediators such as cytokines, a large number of chemokines, and other biologically active molecules ${ }^{41}$ before adhesion to the vessel walls and transmigration take place. Therefore, we investigated the gene expression of additional chemokines and studied the presence of inflammatory cells by immunohistochemistry. We could show that a single-dose $\gamma$-irradiation induced a fast and early up-regulation of CXC-chemokines (CXCL1, CXCL2, CXCL5, and CXCL8), CC-chemokines (MCP-1/ CCL2 and MCP-3/CCL7), and the CXCR2 receptor in the liver, accompanied by an increased number of neutrophils around the portal vessel walls between and around (myo)fibroblasts but not in the parenchyma (sinusoids). Although it is one of the strongly up-regulated chemokines, CXCL1 was mainly expressed in the parenchyma.

It is known that ionizing radiation gives rise to production of reactive oxygen species (ROS) in irradiated cells and tissues ${ }^{42,43}$ with increased generation of molecules 
such as superoxide radical, hydroxyl radical, and $\mathrm{H}_{2} \mathrm{O}_{2}$ due to oxidative stress. ${ }^{43}$ Furthermore, a link between ROS production after whole body exposure to $\gamma$-irradiation and hepatic injury has been reported in mice. ${ }^{43,44}$ ROS contribute to the expression of a variety of different inflammatory cytokines, chemokines, and adhesion molecules ${ }^{45}$ by activating redox-sensitive transcription factors such as nuclear factor- $\kappa \mathrm{B} .{ }^{46}$

We speculate that ROS act as signaling molecules leading to modulation of crucial events such as elevation of the inflammasome, which is a multiprotein complex that promotes secretion of the proinflammatory genes through activation of caspase- $1 .{ }^{47}$

On the other hand, radiation-induced injury in the vascular endothelium could in turn decrease oxygenation in normal tissue and lead to hypoxia. ${ }^{48,49}$ Reduced tissue oxygen tension induces activation of signaling pathways, which also promotes cell survival largely mediated by a transcription factor such as hypoxia inducible factor- 1 (manuscript in preparation). ${ }^{50}$ Further, hypoxia-induced ROS could also induce chemokines and cytokine synthesis as well as upregulation of adhesion molecules gene(s). ${ }^{45,51,52}$

In our current study, we showed for the first time a localized up-regulation of several chemokines, such as MCP-1/CCL2, CXCL1, and IL-8/CXCL8, which is accompanied by a recruitment of the inflammatory cells limited to that area. It has been shown that MCP-1/CCL2 serves as an indirect mediator to attract neutrophils through the production of $\mathrm{LTB}_{4}$ in a murine model of septic peritonitis. ${ }^{53}$ Additionally, neutralization of MCP-1/CCL2 activity in a lipopolysaccharide model of inflammation resulted not only in decreased monocytes accumulation within the intestinal muscularis, but polymorphonuclear leukocytes infiltration was also significantly reduced. ${ }^{54}$ ROS produced by ischemia/reperfusion injury significantly increased the mRNA expression of MCP-1/CCL2 in the heart, ${ }^{55}$ as has also been shown for the hepatotoxin carbon tetrachloride, ${ }^{56}$ as well as whole lung irradiation in mice. ${ }^{57} \mathrm{IL}-8 / \mathrm{CXCL} 8$ has been considered to be of crucial importance for recruitment of granulocytes in different tissues. ${ }^{7}$ In previous work, ${ }^{25}$ however, we were surprised to find a massive up-regulation of CXCL8 gene expression in the liver of rats treated with turpentine oil intramuscularly without detecting any granulocyte infiltration. Because LMFs constitutively express most of the chemokines and cytokines up-regulated by $\gamma$-irradiation in the liver and in isolated cells, they could be responsible for recruitment of neutrophil around the portal vessels. Together with the data presented here, our experience suggests that contemporary up-regulation of gene expression of several chemokines (mainly in myofibroblasts) may be necessary to induce recruitment of inflammatory cells in a localized area beginning around the walls of vessels. In fact, intraperitoneal administration of MCP-1/ CCL2 antibody 30 minutes before irradiation reverted the inhibition of IFN- $\gamma$ gene expression in the liver but did not contribute to a significant reduction of the number of neutrophils. However, we cannot rule out that a higher amount of antibody administration earlier or later, before or during irradiation, may inhibit recruitment of neutrophils into the portal field. The data may suggest that contemporary administration of antibodies specific for the different chemokines is necessary to reduce neutrophils migration into the portal area. Based on these results, we can speculate that CCL2 has an inhibitory effect on IFN- $\gamma$ gene expression, as has been observed in T-cells. ${ }^{58}$ The reason for the lack of increase of macrophages and the consequence of this phenomenon will be a matter for future investigation.

In conclusion, we found recruited neutrophils but no mononuclear phagocytes attached to the portal vessels and to portal (myo)fibroblasts in the liver of irradiated rats. Furthermore, fast and early induction of gene expression of several chemokines (CXCL1, CXCL2, CXCL5, CXCL8, CCL2, and CCL7) and the chemokines receptor CXCR2 gene expression in irradiated liver tissue and microdissected cells of the portal area were observed. Several chemokines may be necessary in neutrophils recruitment, adhesion, and transmigration induced by $\gamma$-irradiation in the rat liver. The induction of the mediators in cells of portal area (mainly myofibroblasts) may happen through molecules such as ROS. Because tissue damage observed under these conditions is of limited extent, the often reported sensitivity of liver tissue to $\gamma$-irradiation may be due to the frequently concomitant administration of chemotherapy or to the presence of chronic liver disease.

\section{Acknowledgments}

We acknowledge the invaluable help of Mrs Sonja Heyroth and Mrs Anke Herbst for their expert technical assistance.

This work is dedicated to Professor Dr. Meyer zum Büschenfelde on the occasion of his 80th birthday.

\section{References}

1. Shim SJ, Seong J, Lee IJ, Han KH, Chon CY, Ahn SH: Radiationinduced hepatic toxicity after radiotherapy combined with chemotherapy for hepatocellular carcinoma. Hepatol Res 2007, 37:906-913

2. Cheng JC, Wu JK, Huang CM, Huang DY, Cheng SH, Lin YM, Jian JJ, Yang PS, Chuang VP, Huang AT: Radiation-induced liver disease after radiotherapy for hepatocellular carcinoma: clinical manifestation and dosimetric description. Radiother Oncol 2002, 63:41-45

3. Marra F: Chemokines in liver inflammation and fibrosis. Front Biosci 2002, 7:d1899-d1914

4. Bozic CR, Kolakowski LF Jr, Gerard NP, Garcia-Rodriguez C, von Uexkull-Guldenband C, Conklyn MJ, Breslow R, Showell HJ, Gerard $\mathrm{C}$ : Expression and biologic characterization of the murine chemokine KC. J Immunol 1995, 154:6048-6057

5. Rossi DL, Hurst SD, Xu Y, Wang W, Menon S, Coffman RL, Zlotnik A Lungkine, a novel CXC chemokine, specifically expressed by lung bronchoepithelial cells. J Immunol 1999, 162:5490-5497

6. Wolpe SD, Sherry B, Juers D, Davatelis G, Yurt RW, Cerami A: Identification and characterization of macrophage inflammatory protein 2. Proc Natl Acad Sci USA 1989, 86:612-616

7. Harris JG, Flower RJ, Watanabe K, Tsurufuji S, Wolitzky BA, Perrett $\mathrm{M}$ : Relative contribution of the selectins in the neutrophil recruitment caused by the chemokine cytokine-induced neutrophil chemoattractant (CINC). Biochem Biophys Res Commun 1996, 221:692-696

8. Ajuebor MN, Flower RJ, Hannon R, Christie M, Bowers K, Verity A Perretti M: Endogenous monocyte chemoattractant protein-1 recruits monocytes in the zymosan peritonitis model. J Leukoc Biol 1998, 63: $108-116$ 
9. Frangogiannis NG, Smith CW, Entman ML: The inflammatory response in myocardial infarction. Cardiovasc Res 2002, 53:31-47

10. Baggiolini M: Chemokines and leukocyte traffic. Nature 1998, 392:565-568

11. Chandrasekar B, Smith JB, Freeman GL: Ischemia-reperfusion of rat myocardium activates nuclear factor-KappaB and induces neutrophil infiltration via lipopolysaccharide-induced CXC chemokine. Circulation 2001, 103:2296-2302

12. Gerard C, Rollins BJ: Chemokines and disease. Nat Immunol 2001, 2:108-115

13. Woo CW, Siow YLOK: Homocysteine induces monocyte chemoattractant protein-1 expression in hepatocytes mediated via activator protein-1 activation. J Biol Chem 2008, 283: 1282-1292

14. Yoshimura T, Takahashi M: IFN-gamma-mediated survival enables human neutrophils to produce MCP-1/CCL2 in response to activation by TLR ligands. J Immunol 2007, 179:1942-1949

15. Izikson L, Klein RS, Charo IF, Weiner HL, Luster AD: Resistance to experimental autoimmune encephalomyelitis in mice lacking the CC chemokine receptor (CCR)2. J Exp Med 2000, 192:1075-1080

16. Peters W, Scott HM, Chambers HF, Flynn JL, Charo IF, Ernst JD: Chemokine receptor 2 serves an early and essential role in resistance to Mycobacterium tuberculosis. Proc Natl Acad Sci USA 2001, 98:7958-7963

17. Boring L, Gosling J, Cleary M, Charo IF: Decreased lesion formation in CCR2-1- mice reveals a role for chemokines in the initiation of atherosclerosis. Nature 1998, 394:894-897

18. Hogaboam CM, Bone-Larson CL, Steinhauser ML, Matsukawa A, Gosling J, Boring L, Charo IF, Simpson KJ, Lukacs NW, Kunkel SL: Exaggerated hepatic injury due to acetaminophen challenge in mice lacking C-C chemokine receptor 2. Am J Pathol 2000, 156:1245-1252

19. Tsou CL, Peters W, Si Y, Slaymaker S, Aslanian AM, Weisberg SP, Mack M, Charo IF: Critical roles for CCR2 and MCP-3 in monocyte mobilization from bone marrow and recruitment to inflammatory sites. J Clin Invest 2007, 117:902-909

20. Tessier PA, Naccache PH, Clark-Lewis I, Gladue RP, Neote KS, McColl SR: Chemokine networks in vivo: involvement of $\mathrm{C}-\mathrm{X}-\mathrm{C}$ and $\mathrm{C}-\mathrm{C}$ chemokines in neutrophil extravasation in vivo in response to TNF-alpha. J Immunol 1997, 159:3595-3602

21. Lentsch AB, Yoshidome H, Cheadle WG, Miller FN, Edwards MJ Chemokine involvement in hepatic ischemia/reperfusion injury in mice: roles for macrophage inflammatory protein-2 and Kupffer cells. Hepatology 1998, 27:507-512

22. Christiansen H, Batusic D, Saile B, Hermann RM, Dudas J, RaveFrank M, Hess CF, Schmidberger H, Ramadori G: Identification of genes responsive to gamma radiation in rat hepatocytes and rat liver by cDNA array gene expression analysis. Radiat Res 2006, 165:318-325

23. Christiansen H, Sheikh N, Saile B, Reuter F, Rave-Frank M, Hermann RM, Dudas J, Hille A, Hess CF, Ramadori G: x-Irradiation in rat liver: consequent upregulation of hepcidin and downregulation of hemojuvelin and ferroportin-1 gene expression. Radiology 2007, 242:189-197

24. Moriconi F, Christiansen $H$, Raddatz D, Dudas J, Hermann RM, Rave-Frank M, Sheikh N, Saile B, Hess CF, Ramadori G: Effect of radiation on gene expression of rat liver chemokines: in vivo and in vitro studies. Radiat Res 2008, 169:162-169

25. Sheikh N, Tron K, Dudas J, Ramadori G: Cytokine-induced neutrophil chemoattractant- 1 is released by the noninjured liver in a rat acutephase model. Lab Invest 2006, 86:800-814

26. Dudas J, Mansuroglu T, Batusic D, Saile B, Ramadori G: Thy-1 is an in vivo and in vitro marker of liver myofibroblasts. Cell Tissue Res 2007, 329:503-514

27. Ramadori G, Sipe JD, Dinarello CA, Mizel SB, Colten HR: Pretranslational modulation of acute phase hepatic protein synthesis by murine recombinant interleukin 1 (IL-1) and purified human IL-1. J Exp Med 1985, 162:930-942

28. Espina V, Wulfkuhle JD, Calvert VS, VanMeter A, Zhou W, Coukos G, Geho DH, Petricoin EF, III, Liotta LA: Laser-capture microdissection. Nat Protoc 2006, 1:586-603

29. Ramadori G, Moebius U, Dienes HP, Meuer S, Meyer Zum Buschenfelde $\mathrm{KH}$ : Lymphocytes from hepatic inflammatory infiltrate kill rat hepatocytes in primary culture. Comparison with peripheral blood Iymphocytes. Virchows Arch B Cell Pathol Incl Mol Pathol 1990, 59:263-270

30. Tello K, Christiansen H, Gurleyen H, Dudas J, Rave-Frank M, Hess
CF, Ramadori G, Saile B: Irradiation leads to apoptosis of Kupffer cells by a Hsp27-dependant pathway followed by release of TNFalpha. Radiat Environ Biophys 2008, 47:389-397

31. Taub DD, Longo DL, Murphy WJ: Human interferon-inducible protein-10 induces mononuclear cell infiltration in mice and promotes the migration of human $\mathrm{T}$ Iymphocytes into the peripheral tissues and human peripheral blood lymphocytes-SCID mice. Blood 1996, 87:1423-1431

32. Sprenger H, Kaufmann A, Garn H, Lahme B, Gemsa D, Gressner AM: Induction of neutrophil-attracting chemokines in transforming rat hepatic stellate cells. Gastroenterology 1997, 113:277-285

33. Knittel T, Kobold D, Saile B, Grundmann A, Neubauer K, Piscaglia F, Ramadori G: Rat liver myofibroblasts and hepatic stellate cells: different cell populations of the fibroblast lineage with fibrogenic potential. Gastroenterology 1999, 117:1205-1221

34. Krohn N, Kapoor S, Enami Y, Follenzi A, Bandi S, Joseph B, Gupta S: Hepatocyte transplantation-induced liver inflammation is driven by cytokines-chemokines associated with neutrophils and Kupffer cells. Gastroenterology 2009, 136:1806-1817

35. Mosher B, Dean R, Harkema J, Remick D, Palma J, Crockett E: Inhibition of Kupffer cells reduced CXC chemokine production and liver injury. J Surg Res 2001, 99:201-210

36. Dudas J, Mansuroglu T, Batusic D, Ramadori G: Thy- 1 is expressed in myofibroblasts but not found in hepatic stellate cells following liver injury. Histochem Cell Biol 2009, 131:115-127

37. Maj JG, Paris F, Haimovitz-Friedman A, Venkatraman E, Kolesnick R, Fuks Z: Microvascular function regulates intestinal crypt response to radiation. Cancer Res 2003, 63:4338-4341

38. Gaugler MH, Squiban C, Claraz M, Schweitzer K, Weksler B, Gourmelon $\mathrm{P}$, Van der Meeren $\mathrm{A}$ : Characterization of the response of human bone marrow endothelial cells to in vitro irradiation. $\mathrm{Br} J$ Haematol 1998, 103:980-989

39. Rej R: Aminotransferases in disease. Clin Lab Med 1989, 9:667-687

40. Moriconi F, Malik I, Ahmad G, Dudas J, Rave-Frank M, Vorwerk H, Hille A, Hess CF, Ramadori G, Christiansen $\mathrm{H}$ : Effect of irradiation on gene expression of rat liver adhesion molecules: in vivo and in vitro studies. Strahlenther Onkol 2009, 185:460-468

41. Ramaiah SK, Jaeschke $\mathrm{H}$ : Role of neutrophils in the pathogenesis of acute inflammatory liver injury. Toxicol Pathol 2007, 35:757-766

42. Leach JK, Van TG, Lin PS, Schmidt-Ullrich R, Mikkelsen RB: Ionizing radiation-induced, mitochondria-dependent generation of reactive oxygen/nitrogen. Cancer Res 2001, 61:3894-3901

43. Riley PA: Free radicals in biology: oxidative stress and the effects of ionizing radiation. Int J Radiat Biol 1994, 65:27-33

44. An JH, Kim J, Seong J: Redox signaling by ionizing radiation in mouse liver. Ann NY Acad Sci 2004, 1030:86-94

45. Lin BR, Yu CJ, Chen WC, Lee HS, Chang HM, Lee YC, Chien CT, Chen CF: Green tea extract supplement reduces D-galactosamineinduced acute liver injury by inhibition of apoptotic and proinflammatory signaling. J Biomed Sci 2009, 16:35

46. Droge W: Free radicals in the physiological control of cell function. Physiol Rev 2002, 82:47-95

47. Franchi L, Eigenbrod T, Munoz-Planillo R, Nunez G: The inflammasome: a caspase-1-activation platform that regulates immune responses and disease pathogenesis. Nat Immunol 2009, 10:241-247

48. Kiani MF, Ansari R, Gaber MW: Oxygen delivery in irradiated normal tissue. J Radiat Res (Tokyo) 2003, 44:15-21

49. Stone HB, McBride WH, Coleman CN: Modifying normal tissue damage postirradiation: report of a workshop sponsored by the Radiation Research Program, National Cancer Institute, Bethesda, Maryland, September 6-8, 2000. Radiat Res 2002, 157:204-223

50. Semenza GL, Agani F, Feldser D, Iyer N, Kotch L, Laughner E, Yu A: Hypoxia, HIF-1, and the pathophysiology of common human diseases. Adv Exp Med Biol 2000, 475:123-130

51. Bremer C, Bradford BU, Hunt KJ, Knecht KT, Connor HD, Mason RP Thurman RG: Role of Kupffer cells in the pathogenesis of hepatic reperfusion injury. Am J Physiol 1994, 267:G630-G636

52. Ghezzi P, Dinarello CA, Bianchi M, Rosandich ME, Repine JE, White CW: Hypoxia increases production of interleukin-1 and tumor necrosis factor by human mononuclear cells. Cytokine 1991, 3:189-194

53. Matsukawa A, Hogaboam CM, Lukacs NW, Lincoln PM, Strieter RM, Kunkel SL: Endogenous monocyte chemoattractant protein-1 (MCP-1) 
protects mice in a model of acute septic peritonitis: cross-talk between MCP-1 and leukotriene B4. J Immunol 1999, 163:6148-6154

54. Turler A, Schwarz NT, Turler E, Kalff JC, Bauer AJ: MCP-1 causes leukocyte recruitment and subsequently endotoxemic ileus in rat. Am J Physiol Gastrointest Liver Physiol 2002, 282:G145-G155

55. Morimoto $H$, Hirose $M$, Takahashi $M$, Kawaguchi $M$, Ise $H$, Kolattukudy PE, Yamada M, Ikeda U: MCP-1 induces cardioprotection against ischaemia/reperfusion injury: role of reactive oxygen species. Cardiovasc Res 2008, 78:554-562

56. Czaja MJ, Geerts A, Xu J, Schmiedeberg P, Ju Y: Monocyte chemoat- tractant protein 1 (MCP-1) expression occurs in toxic rat liver injury and human liver disease. J Leukoc Biol 1994, 55:120-126

57. Ao X, Zhao L, Davis MA, Lubman DM, Lawrence TS, Kong FM: Radiation produces differential changes in cytokine profiles in radiation lung fibrosis sensitive and resistant mice. J Hematol Oncol 2009, 2:6

58. Hogaboam CM, Lukacs NW, Chensue SW, Strieter RM, Kunkel SL: Monocyte chemoattractant protein- 1 synthesis by murine lung fibroblasts modulates CD4+ T cell activation. J Immunol 1998, 160:4606-4614 